\title{
Long-Term Outcome After Operative Management of Talus Fractures
}

\author{
Wouter Vints, MD1, Giovanni Matricali, MD, PhD2,3,4, Eric Geusens, MD5, Stefaan Nijs, MD, \\ $\mathrm{PhD}_{1,3}$, and Harm Hoekstra, MD, PhD, FEBS 1,3
}

1Department of Trauma Surgery, University Hospitals Leuven, Leuven, Belgium

2Department of Orthopaedic surgery, University Hospitals Leuven, Leuven, Belgium

3Department of Development and Regeneration, KU Leuven-University of Leuven, Leuven, Belgium

4Institute for Orthopaedic Research and Training (IORT), KU Leuven-University of Leuven, Leuven, Belgium

${ }_{5}$ Department of Radiology, University Hospitals Leuven, Leuven, Belgium

Corresponding Author:

Harm Hoekstra, MD, PhD, FEBS, Department of Trauma Surgery,

University Hospitals Leuven, Herestraat 49, B-3000 Leuven, Belgium.

Email: harm.hoekstra@uzleuven.be

Abstract

Background: Controversies remain regarding the preferred treatment strategy for talus fractures. The primary goal of this study was to evaluate the long-term outcome after operative management of talus fractures. Secondarily, we identified those factors that affected the outcome and defined strategies to improve the outcome.

Methods: This is a retrospective outcome study of 84 patients with an average follow-up time of 9.1 years. We assessed the functional results, return to daily activities, and general health status using the Foot Function Index$5 \mathrm{pt}$, a numeric rating scale for pain, and the Short Form-36 Health Survey. Furthermore, we conducted a correlation analysis between the outcomes and 14 demographic, clinical, and radiologic variables.

Results: We found moderate mean Foot Function Index pain and disability scores of 30.2 and 28.7, respectively. The mean numeric rating scale score was 3.2. Of all responders, $41 \%$ (27/66) did not return to their daily activities. We reported low physical, but good mental, Short Form-36 component summary scores of 42.7 and 48.3 , respectively. We recorded a complication rate of $56 \%$. Osteoarthritis, articular incongruence and talus body fractures correlated significantly with a poorer functional outcome. Delayed surgery after trauma was associated with better outcome measures.

Conclusions: Talus fractures have a major long-term impact on ankle and hindfoot function and on physical health. Success of operative treatment depends on the occurrence of osteoarthritis postoperatively, type of fracture, and quality of fracture reduction. Because only the latter is modifiable, efforts should be made to restore articular congruence in order to improve the outcome. Therefore, we recommend reviewing the quality of the reduction postoperatively on CT. Furthermore, talus fractures should not be considered operative emergencies, but rather treated after recovery of the soft-tissues.

Level of Evidence: Level III, comparative study.

Keywords: operative treatment, talus fractures, determinants of outcome

Talus fractures are rare and account for $0.3 \%$ of all fractures and only $3.4 \%$ of foot fractures. 19 With no less than 7 articular surfaces, the talus provides the junction between the lower leg and the foot.2,25 Articular reduction and fixation of talus fractures is often technically challenging, though in the end crucial for ankle and hindfoot function. Nevertheless, there are only a limited number of studies on long-term outcome after operative management of talus fractures.12,14,21,23 Moreover, operative techniques have considerably been refined during the last 20 years, and hence the proper operative strategy remains a topic of discussion.28,30,32 Our primary endpoint was assessing the long-term functional outcome and general health status after operative management of acute talus fractures. Secondarily, we identified the clinical and adiographic parameters that influenced the outcome in order to improve treatment strategies and outcome of talus fractures. 


\section{Methods}

\section{Patients and Setting}

Eighty-four consecutive adult ( $\geqslant 18$ years) patients with 85 talus fractures were included and 66 patients did respond in this retrospective single-center cohort study. All included patients were treated operatively for an acute talus fracture within 30 days after trauma at the Department of Trauma Surgery or the Department of Orthopaedic Surgery of the University Hospitals Leuven, Belgium, between January 2000 and July 2016. Notably, patients with isolated osteochondral lesions were excluded. The identification/inclusion process is depicted in Figure 1. This study was performed according to the Belgian legislation after approval by the ethics committee of University Hospitals Leuven.

\section{Demographic, Clinical, and Radiologic Characteristics}

We defined 17 study variables, of which 8 were demographic (age at the time of trauma, gender, American Society of Anesthesiologists [ASA] score, body mass index [BMI], smoking, daily alcohol use, diabetes mellitus, and other cardiovascular risk factors [CVRFs]) and 9 were clinical characteristics (fracture type, associated fractures of the same foot or ankle, open fractures, time of treatment, type of definite surgery, operative approach, malleolar osteotomy, postoperative complications, and reinterventions).

CVRFs were categorized as follows: age of 55 years and over, overweight (BMI more than 25), smoking, daily alcohol use, diabetes mellitus, and other CVRFs (hypercholesterolemia, dyslipidemia, hypertension, or current cardiovascular diseases). Fracture type was defined as either body, neck, and/or head fracture. Neck and head fractures were classified by the Hawkins classification, modified by Canale and Kelly (Supplemental Addendum I).5 Body fractures were classified according to Sneppen et al (Supplemental Addendum II).31 Open fractures were classified according to Gustilo-Anderson classification system.20

Time of treatment was displayed as early (time from trauma to surgery less than 24 hours), delayed (more than 24 hours) or delayed-staged (closed reduction with external fixation [CREF] before definitive surgery). Time to definitive surgery was registered in all patients treated according to a delayed (-staged) surgery protocol. Definitive surgery was classified as (plate and) screw osteosynthesis [(P)SOS], K-wiring, CREF, primary arthrodesis, or total talus transplant with allograft. Operative approaches were categorized as anterior, anteromedial, anterolateral, posteromedial, or posterolateral. 9 In addition, we registered whether a single or dual approach (triple approach $\mathrm{n}=$ 1) was performed. Postoperative complications were operative site infection, articular incongruence, nonunion, avascular necrosis (AVN), osteoarthritis and other postoperative complications (intra-articular material, talar impingement, or equinus deformity). Articular incongruence was defined on postoperative radiographs or CT when available, as an intra-articular gap or step of more than $2 \mathrm{~mm}$, or more than 5 degrees angulation in any plane.13 Nonunion was defined at 9 months postoperatively as a not completely healed fracture without progression toward healing over the 3 preceding months. $\mathrm{AVN}$ and posttraumatic peritalar osteoarthritis were evaluated on follow-up radiographs. Osteoarthritis was subdivided by location in ankle (tibiotalar and/or fibulotalar), other peritalar, or both ankle and other peritalar osteoarthritis. Reinterventions were noted as reintervention rate and total number of reinterventions. Reintervention rate is the number of patients with 1 or more reinterventions, categorized as material removal, secondary arthrodesis, ankle prosthesis, and other reinterventions (reoperation, arthrolysis, [partial-] talectomy, adjustable hybrid external fixator, nonunion repair, and arthroscopic debridement).

\section{Outcome Measures}

All included patients were sent a questionnaire to evaluate the functional outcome and general health status (Supplemental Addendum IV). The date of completing the questionnaire was defined as the end of follow-up. The Foot Function Index (FFI)-5pt Dutch version was used to assess the functional outcome in terms of pain and disability. The FFI-5pt ranges from 0 to 100. A higher score implies worse functionality. Additionally, a numeric rating scale (NRS) was used to measure pain on a scale from 0 (no pain) to 10 (worst imaginable pain). Quality of life was assessed using the Short Form-36 Health Survey (SF-36) Dutch version.

SF-36 also ranges from 0 to 100, but a higher score indicates a better general health. Both the FFI and the SF-36 are standardized questionnaires, with verified reproducibility, validated for the Dutch language.1,22 Furthermore, we assessed if patients returned to their daily activities. 
SF-36 subscale scores were calculated using standard scoring algorithms according to Ware et al 37 and the physical (PCS) and mental (MCS) component summaries were calculated using country-specific mean and standard deviations, United States factor score coefficients, as advised by Taft et al. 3 As such values do not exist for Belgium, we chose the mean PCS and MCS scores of the Netherlands, derived from the "National Study" as reference for norm-based scoring.1 A score of 50 on the PCS or MCS corresponds to the mean value of the Dutch population. Patients were categorized as unable to return to their daily activities if they indicated to have another job as a consequence of their foot/ankle injury, the same job with adjustments, to be no longer capable to work because of their foot/ankle, or to be retired and hindered by their foot/ankle in their daily activities.

\section{Statistical Analysis}

All data were statistically analyzed using IBM SPSS Statistics 24.0 (SPSS Inc, Chicago, IL). The Mann-Whitney $U$ test was used for comparing nonparametric variables. Nominal variables were compared using $\chi^{2}$ or Fisher exact statistics. A statistically significant $\chi_{2}$ test in case of a multinominal or categorical variable was followed by post hoc multiple pairwise comparisons. Correlations with nominal outcome variables were tested with logistic regression. Correlations with continuous outcome variables were tested with Spearman correlation for nominal and Pearson correlation for continuous predicting parameters. For each outcome parameter, we conducted a stepwise multiple regression analysis with all significantly correlated predicting variables. A significance level of $P<.05$ was accepted for all tests.

\section{Results}

\section{Demographic, Clinical, and Radiologic Characteristics}

All patient characteristics are shown in Table 1 (see also Supplemental Table S1). A total of 66/84 (78.6\%) patients with 67 talus fractures responded to our questionnaire (Supplement Table S8). The median clinical follow-up time was 106 (IQR 62-154) months, whereas the median radiologic follow-up time was 22 (IQR 9-45) months. Responders and nonresponders differed significantly in ASA score at the time of trauma $(P=.039)$. Post hoc multiple pairwise comparison showed a significant difference in number of patients with an ASA 3 score, which was 0/63 and 2/17 for responders and nonresponders, respectively. The quality of reduction was assessed postoperatively on both radiographs and CT scan. A postoperative CT was performed in $77.6 \%$ of fractures: $16.4 \%$ had a CT scan in the first 30 days postoperatively and $58.2 \%$ in the first year postoperatively, though most patients within 3 months.

\section{Functional Outcome and General Health Status}

Mean outcome scores of all responding patients are displayed in Table 2 (see also Supplement Table S2). On the total FFI, 7/66 patients (10.6\%) scored 0, meaning they experienced neither pain nor disability due to their foot in the last week of follow-up. Eight of 66 patients (12.1\%) indicated to have no pain on the FFI pain scale. Eleven of 66 patients (16.7\%) indicated to have no disabilities on the FFI disability scale (Supplement Table S4). On the NRS pain score, $14 / 63$ patients (22.2\%) scored 0 , whereas $18 / 63$ patients (28.6\%) scored 5 or more on 10 . SF-36 outcomes indicate a major impact of talus fractures on physical health status, whereas the mental health status was comparable to the reference population (reference value 50) (Supplement Table S5).

\section{Outcome Measures Intercorrelation}

FFI pain, FFI disability, NRS pain, and SF-36 PCS scores were all highly intercorrelated ( $R^{2}$ values ranging from 0.501 to 0.723 , all $P<.001)$. Return to daily activity was also correlated with these outcome measures $\left(R^{2}\right.$ values ranging from 0.146 to 0.360 , all $P<.01)$. SF-36 MCS scores were significantly correlated with FFI pain $\left(R^{2}=0.142, P<.01\right)$, FFI difficulty $\left(R^{2}=0.089, P<.05\right)$, and NRS pain scores $\left(R^{2}=0.117, P<.01\right)$ (Supplement Table S6).

\section{Factors Affecting Outcome}

Correlations between patient characteristics and the FFI, NRS pain, and SF-36 are displayed in Table 3. One of the surgeons at our institution operated on $55 \%$ of all talus fractures. His patient-reported outcome was better on every scale compared to other surgeons', which was statistically significant for FFI pain $\left(R^{2}=0.077, P=.025\right)$ (Supplement Table S9). In 3 fractures, definite treatment was performed by a fellow. All other fractures were treated by staff surgeons. 
After stepwise multiple regression analysis, the presence of osteoarthritis turned out to be the most predictive factor of poor outcome for all our outcome measures, except for NRS pain, where the presence of a complication was the most predictive factor, for return to daily activity, where a head fracture seemed of major impact, and except for SF$36 \mathrm{MCS}$, where the presence of a body fracture was the most predictive factor. In the absence of complications, SF36 scores are comparable to the general population, as shown in Figure 2. Other factors that were derived from the stepwise multiple regression analysis were as follows: body fractures for the FFI pain (model $R^{2}=0.414$ ), delayed surgery and nonunion for the FFI disability (model $R^{2}=0.409$ ), body fractures for the NRS pain (model $R^{2}=0.408$ ), articular incongruence, delayed surgery and primary arthrodesis for the SF-36 PCS (model $R^{2}=0.512$ ), and open fractures, dual approach, and ankle osteoarthritis for return to daily activity (model Nagelkerke $R^{2}=0.506$ ). All $P$ values of the above-mentioned models were lower than 0.001 , and only delayed surgery was of positive influence on the outcome measures. For the SF-36 MCS, stepwise multiple regression analysis showed a model in which the presence of a body fracture was associated with worse SF-36 scores (model $R^{2}=0.123, P=.005$ ) (Supplement Table S7).

\section{Most Important Determinants of Outcome}

Postoperative complications, fracture type, and time to surgery were identified as important outcome predictors. Postoperative complications (ie, osteoarthritis) were the most important determinants affecting the outcome (Table 3).

Medial osteotomy was associated with higher ankle osteoarthritis rates $\left(R^{2}=0.154, P=.001\right)$. Other peritalar osteoarthritis rates were higher for open fractures $\left(R^{2}=0.069, P=.031\right)$ and increasing Gustilo-Anderson grade $\left(R^{2}\right.$ $=0.078 P=.022)$. When flap reconstruction was required for wound closure $(3 / 65$ of the responding patients), none of the patients returned to daily activities and outcome scores were very poor (Figure 3). Some complications required operative treatment with secondary arthrodesis. In our study, secondary arthrodesis rates were $23.2 \%$ at the 5 -year and $25.7 \%$ at the 10 -year follow-up (Figure 4 ). The 5-year secondary arthrodesis rates were $44.4 \%$ for head, $20.4 \%$ for neck, and $24.7 \%$ for body fractures. Taking primary and secondary arthrodesis together in our correlation analysis, we found significant correlations with poor FFI, VAS, and SF-36 PCS scores, as well as failure to return to daily activity ( $R^{2}$ values ranging from 0.071 to 0.175 ; all $\left.P<.05\right)$.

Articular incongruence as an early predictor of osteoarthritis was found to be associated with fracture severity. Articular incongruence rate was $0 / 10$ for Hawkins 1 type of neck fractures, which differed significantly from Hawkins $2(5 / 12)$, Hawkins $3(1 / 3)$, and Hawkins 4 fractures $(2 / 2)(P=.013)$. In talus body fractures, articular incongruence rate was (in order from high to low) 3/6 in Sneppen 5, 3/7 in Sneppen 2, 3/8 in Sneppen 3, 1/7 in Sneppen 4, and $2 / 17$ in combined body fracture types. Furthermore, articular incongruence was associated with a posteromedial approach $\left(R^{2}=0.133, P=.003\right)$ and significantly lower in an anterolateral approach $\left(R^{2}=0.071, P=.030\right)$.

Regarding fracture type, the presence of a body fracture was associated with the poorest outcome scores. Sneppen 5 fractures had the worst outcome scores (Figure 5) (Supplement Table S3). All Sneppen 5 fractures in our study ( =6) had postoperative complications.

Also, the time of treatment seemed an important factor in the outcome of talus fractures. More specifically, delayed surgery was the most important factor associated with better outcome scores (Table 3). Lower osteoarthritis rates (especially ankle osteoarthritis) were observed in patients treated delayed $(31.7 \%$ vs $64.0 \%$ for delayed vs early surgery, respectively, $P=.010)$. A delayed-staged surgery protocolwas mainly used for the treatment of talus body fractures (particularly in Sneppen 5) and therefore correlated with less favorable outcome scores (Figure 6).

\section{Discussion}

The aim of this study was to evaluate the functional outcome and general health status after the operative treatment of talus fractures and define those variables that affect the outcome in order to define strategies to improve the outcome. Our patients reported mean FFI-5pt pain and disability scores of 30.2 and 28.7 , respectively. Overall, $58 / 66$ (87.9\%) of the responding patients reported pain and 55/66 (83.3\%) disability during daily activities at a mean followup of 109 months. Regarding NRS pain scores, 18/63 (28.6\%) of the patients scored 5/10 or higher at rest. Also, $27 / 66(40.9 \%)$ of the responding patients did not return to their daily activities. Vallier et al 34 reported for talus neck fractures comparable FFI scores of 25.3 and 34.4, respectively. For talus body fractures, Vallier et al 35 and Sen et al 30 found worse mean FFI pain and disability scores; however, they excluded lateral and posterior process fractures. Talus fractures have an important (negative) impact on physical health (PCS 42.7), whereas mental health (MCS 48.3) 
was comparable to the reference values of the general Dutch population. As previously reported by others, outcome measures were highly dependent on the presence of postoperative complications.10 In the absence of postoperative complications, physical SF-36 scores were comparable to those of the general population as well. Patients who required flap reconstruction (Gustilo- Anderson grade $3 \mathrm{~b}$ and $3 \mathrm{c}$ open fractures) showed very poor outcome scores; none of them returned to daily activities. Because of the small number, however, significance was low (except for return to daily activities). In our series, $25.7 \%$ of cases were treated with secondary arthrodesis by the end of followup. This is comparable with Fournier et al,13 who described a secondary arthrodesis rate of $25.4 \%$. In concordance with their study, secondary arthrodesis was mostly performed in the first 5 years (23.2\%).13 This leads to loss of function of the joint and is associated with poor functional outcomes.5,13 Arthrodesis rates were highest in talar head fractures, which were associated with a lower return to daily activities.

Unfortunately, talus fractures are associated with high complication rates.10,13,25,34 We found a postoperative complication rate of $56.5 \%$, mainly osteoarthritis $(42.4 \%)$, which in turn affected the outcome most. In concordance with other studies, we found higher rates of osteoarthritis with longer radiologic follow-up.25 Although we had a longer mean clinical follow-up time compared with other studies (9.1 years), mean radiologic follow-up time was shorter (3.1 years). Hence, the actual osteoarthritis rate is probably higher and may explain our rather low rate as compared to other long-term studies (37\%-100\%, with follow-up times of 6-9.8 years).13,15,23,25 Lower osteoarthritis rates were observed in patients in whom definitive surgery was delayed.

The second most important postoperative complication was articular incongruence, which was strongly associated with poor FFI pain, NRS pain and SF-36 PCS scores. The observed postoperative articular incongruence rate was $18 / 79$ (22.8\%) and resembles previous measurements that vary from $25 \%$ to $33 \% .13,25$ Postoperative articular incongruence is considered a predictor of osteoarthritis at longer follow-up; however, we could not prove this.28 This may be explained by the difference in mean radiologic follow-up in patients with articular incongruence (osteoarthritis vs nonosteoarthritis, 52.5 vs 17.6 months, respectively). To reduce articular incongruence rates, a CT is indispensable to accurately classify and guide treatment decision making preoperatively. 6,9,13,28 Given the important impact of articular incongruence on outcome, we suggest reviewing the quality of the reduction postoperatively on CT. Already in 1990, Adelaar suggested operative revision in case of more than $5 \mathrm{~mm}$ or $5 \mathrm{degrees}$ postoperative fracture displacement.2

AVN and its influence on treatment outcome is widely studied.10 Especially, displaced talar neck fractures are known to be associated with disruption of most of the talar vascularization, eventually leading to AVN. In the metaanalysis of Dodd et al,10 studies performed from 2000 onward had an overall AVN rate for talar neck fractures of $24.9 \%$. We observed an overall AVN rate of $12.9 \%$, and this did not correlate with poor outcome. Fournier et al 13 reported up to $59 \%$ asymptomatic AVN and only talus collapse was significantly correlated with poor outcome. We had only 3 responders with talar collapse and could not find any significant associations. To reduce AVN rates, some previous studies advocated early stable fixation, which would protect the remaining blood supply.11,14,15,17,19 In contrast, Crist et als stated that early surgery through traumatized soft tissues can even further harm the already damaged blood supply. More recent studies doubt on any relationship between timing of fixation and AVN rates and consider the initial degree of fracture displacement with disruption of the blood supply to be the most important risk factor. 2, 4, 7, $8,11,14,16,18,19,23,24,26,28,34,35$. Furthermore, some authors pointed out that certain operative approaches affect the vascularization and increase the risk for AVN.13,20 We neither found an association between the timing of surgery nor the chosen operative approach and AVN.

Regarding the above-mentioned timing of surgery, we found delayed surgery to be associated with good outcome scores and low ankle osteoarthritis rates, whereas early and delayed-staged surgery were associated with poor outcome. Early surgery seems no longer a valid option. Vallier et al34 advised to delay definitive fixation, to allow healing of the traumatized soft-tissues. Meanwhile, most orthopedic trauma surgeons abandoned the belief that talus fractures are operative emergencies.26 In contrast, a delayed-staged surgery protocol is indicated in case of open wounds, skin necrosis, compromised soft-tissues, or neurovascular injury.4 In our series, the surgeon who performed definitive surgery and the timing of surgery were not significantly associated.

In accordance with the literature, patients with talar body fractures reported the worst outcome scores and showed the highest osteoarthritis rate.11 Sneppen 5 fractures had the worst outcome scores, and all these patients had complications. Improvements in operative techniques have led to a progressive decline of postoperative complications. 27 We found that SOS was associated with lower osteoarthritis rates, more specifically other peritalar than ankle osteoarthritis, whereas three-fourths of all patients treated with K-wires alone developed osteoarthritis. 
Fournier et al 13 also described higher osteoarthritis rates and less stability using K-wire fixation compared to screw osteosynthesis (SOS). Although K-wire fixation is often used for the treatment of comminuted talus fractures, recent studies advocate here the use of plate and screw osteosynthesis (PSOS), because it might better maintain the talus length.12,13 In our study, 1 of 7 patients treated with PSOS did not return to his daily activities. In contrast, after primary arthrodesis $(n=6)$, only 1 patient returned to his daily activities and we measured significantly worse SF-36 PCS scores. Therefore, it is better to limit primary arthrodesis to cases of comminuted fractures with destruction of the respective joint.27 The chosen operative approach had little effect on the outcome in our series.

There were also no differences in complication rates in any of the postoperative complications measured, except for articular incongruence, which was associated with a posteromedial approach, and the rates were significantly lower in an anterolateral approach. Moreover, a medial osteotomy was associated with higher ankle osteoarthritis rates. However, this finding is likely confounded, because fractures requiring a medial osteotomy (ie, talus dome fractures) are often severe injuries that affect the articulation of the ankle, rather than the medial osteotomy itself.

Like every clinical study, this study has some limitations, including the retrospective design and multiple treatment methods by multiple surgeons. Moreover, the clinical and radiologic follow-up differed substantially, which probably led to a lower osteoarthritis ratio. Although relatively large in comparison with previous single-center talus fracture studies, 5, 6, 11,14, 15, 23, 25, 28-30 the small sample size did not allow for Bonferroni correction when presenting statistically significant results. Therefore, $P$ values should be interpreted with care. To create a study without these limitations, we suggest conductinga long-term prospective multicenter study in the future.

In conclusion, we found that the long-term results after operative management of talus fractures are disappointing. Particularly, talus body fractures have a poor prognosis. Talus fractures are rare and our results show better outcome when operative management was performed by an experienced surgeon. Therefore, we advise a low threshold for referral to a trauma center, where these fractures are managed by a dedicated surgeon. The long-term outcome was most affected by osteoarthritis. In general, osteoarthritis is largely unmodifiable. Because postoperative articular incongruence was an important predictor for the occurrence of osteoarthritis, strong efforts should be made to prevent articular incongruence postoperatively, to optimize the outcome. Definitive surgery using exclusively K-wire fixation and primary arthrodesis should be avoided. We recommend reviewing the quality of the reduction postoperatively on CT. Furthermore, immediate definitive surgery is not recommended, because talus fractures are often associated with soft tissue complications; operative delay did not increase the risk of AVN, and delay of surgery was associated with better outcome in our study.

\section{Declaration of Conflicting Interests}

The author(s) declared no potential conflicts of interest with respect to the research, authorship, and/or publication of this article. ICMJE forms for all authors are available online.

\section{Funding}

The author(s) received no financial support for the research, authorship, and/or publication of this article.

\section{Supplementary Material}

Supplemental appendices are available online with this article.

\section{ORCID iD}

Wouter Vints, MD, https://orcid.org/0000-0003-1803-4949

\section{References}

1. Aaronson NK, Muller M, Cohen PDA, et al. Translation, validation, and norming of the Dutch language version of the SF-36 Health Survey in community and chronic disease populations. J Clin Epidemiol. 1998;51(11):1055-1068.

2. Adelaar RS. Fractures of the talus. Instr Course Lect.1990;39:147-156.

3. Brinker MR, O'Connor DP. Nonunions: evaluation and treatment. In: Browner BD, Levine AM, Jupiter JB, Trafton PG, eds. Skeletal Trauma: Basic Science, Management, and Reconstruction. Philadelphia, PA: WB Saunders; 2009:615-708.

4. Buckwalter VJA, Westermann R, Mooers B, Karam M, Wolf B. Timing of surgical reduction and stabilization of talus fracturedislocations. Am J Orthop. 2017;46(6):E408-E413.

5. Canale S, Kelly F. Fractures of the neck of the talus: long term evaluation of seventy-one cases. J Bone Joint Surg Am. 1978;60(2):143-156.

6. Caracchini G, Pietragalla M, De Renzis A, et al. Talar fractures: radiological and CT evaluation and classification systems. Acta Biomed. 2018;89(1):151-165. 
7. Comfort TH, Behrens F, Gaither DW, Denis F, Sigmond M. Long-term results of displaced talar neck fractures. Clin Orthop Relat Res. 1985;199:81-7.

8. Crist BD, Ferguson T, Murtha YM, Lee MA. Surgical timing of treating injured extremities: an evolving concept of urgency. Instr Course Lect. 2013;62(16):17-28.

9. Cronier P, Talha A, Massin P. Central talar fractures-therapeutic considerations. Injury. 2004;35(suppl 2):SB10-SB22. 10. Dodd A, Lefaivre KA. Outcomes of talar neck fractures: a systematic review and meta-analysis. J Orthop Trauma. 2015;29(5):210-215.

11. Elgafy H, Ebraheim NA, Tile M, Stephen D, Kase J. Fractures of the talus: experience of two level 1 trauma centers. Foot Ankle Int. 2000;21(12):1023-1029.

12. Fleuriau Chateau PB, Brokaw DS, Jelen BA, Scheid DK, Weber TG. Plate fixation of talar neck fractures: preliminary review of a new technique in twenty-three patients. J Orthop Trauma. 2002;16(4):213-219.

13. Fournier A, Barba N, Steiger V, et al. Total talar fracture- long-term results of internal fixation of talar fractures. A multicentric study of 114 cases. Orthop Traumatol Surg Res. 2012;98(4)(suppl):S48-S55.

14. Frawley PA, Hart JA, Young DA. Treatment outcome of major fractures of the talus. Foot Ankle Int. 1995;16(6): 339-45. 15. Grob D, Simpson LA, Weber BG, Bray T. Operative treatment of displaced talus fractures. Clin Orthop Relat Res. 1985;199:88-96.

16. Halvorson JJ, Winter SB, Teasdall RD, Scott AT. Talar neck fractures: a systematic review of the literature. J Foot Ankle Surg. 2013;52(1):56-61.

17. Higgins TF, Baumgaertner MR. Diagnosis and treatment of fractures of the talus: a comprehensive review of the literature. Foot Ankle Int. 1999;20(9):595-605.

18. Jordan RK, Bafna KR, Liu J, Ebraheim NA. Complications of talar neck fractures by Hawkins classification: a systematic review. J Foot Ankle Surg. 2017;56(4):817-821.

19. Juliano PJ, Dabbah M, Harris TG. Talar neck fractures. Foot Ankle Clin. 2004;9(4):723-736.

20. Kim PH, Leopold SS. Gustilo-Anderson classification. Clin Orthop Relat Res. 2012;470(11):3270-3274.

21. Kuner EH, Lindenmaier HL, Munst P. Talus fractures. In: Tscherne H, Schatzker J, eds. Major Fractures of the Pilon, the Talus, and the Calcaneus: Current Concepts of Treatment. Berlin: Springer; 1993:71-85.

22. Kuyvenhoven MM, Gorter KJ, Zuithoff $\mathrm{P}$, Budiman-Mak E, Conrad KJ, Post MW. The Foot Function Index with verbal rating scales (FFI-5pt): a clinimetric evaluation and comparison with the original FFI. J Rheumatol. 2002;29(5):1023- 1028.

23. Lindvall E, Haidukewych G, DiPasquale T, Herscovici D Jr, Sanders R. Open reduction and stable fixation of isolated, displaced talar neck and body fractures. J Bone Joint Surg Am. 2004;86(10):2229-2234.

24. Metzger MJ, Levin JS, Clancy JT. Talar neck fractures and rates of avascular necrosis. J Foot Ankle Surg. 1999;38(2):154- 162. 25. OhI X, Harisboure A, Hemery X, Dehoux E. Long-term follow-up after surgical treatment of talar fractures: twenty cases with an average follow-up of 7.5 years. Int Orthop. 2011;35(1):93-99.

26. Patel R, Van Bergeyk A, Pinney S. Are displaced talar neck fractures surgical emergencies? A survey of orthopaedic trauma experts. Foot Ankle Int. 2005;26(5):378-381.

27. Rammelt S, Zwipp H. Talar neck and body fractures. Injury. 2009;40(2):120-135.

28. Saudan M, Peter R, Delmi M. Fractures du col de l'astragale [Fracture of the talus]. Rev Chir Orthop Reparatrice Appar Mot. 2002;88(2):168-176.

29. Schulze W, Richter J, Russe O, Ingelfinger P, Muhr G. Surgical treatment of talus fractures: a retrospective study of 80 cases followed for 1-15 years. Acta Orthop Scand. 2002;73(3):344-351.

30. Sen RK, Tripathy SK, Manoharan SR, Krishnan V, Tamuk T, Jagadeesh V. Long term surgical treatment outcome of talar body fracture. Chin J Traumatol. 2011;14(5):282-287.

31. Sneppen O, Christensen SB, Krogsoe O, Lorentzen J. Fracture of the body of the talus. Acta Orthop Scand. 1977;48(3): 317324.

32. Summers NJ, Murdoch MM. Fractures of the talus: a comprehensive review. Clin Podiatr Med Surg. 2012;29(2):187-203.

33. Taft C, Karlsson J, Sullivan M. Do SF-36 summary component scores accurately summarize subscale scores? Qual Life Res. 2001;10(5):395-404.

34. Vallier HA, Nork SE, Barei DP, Benirschke SK, Sangeorzan BJ. Talar neck fractures: results and outcomes. J Bone Joint Surg Am. 2004;86(8):1616-1624.

35. Vallier HA, Reichard SG, Boyd AJ, Moore TA. A new look at the Hawkins classification for talar neck fractures. J Bone Joint Surg Am. 2014;96(3):192-197.

36. Ware JE, Gandek B. Overview of the SF-36 Health Survey and the International Quality of Life Assessment (IQOLA) Project. J Clin Epidemiol. 1998;51(11):903-912.

37. Ware JE, Snow K, Kosinski M, Gandek B. SF-36 Health Survey: Manual and Interpretation Guide. Boston, MA: The Health Institute, New England Medical Center; 1993. 


\section{Figures}

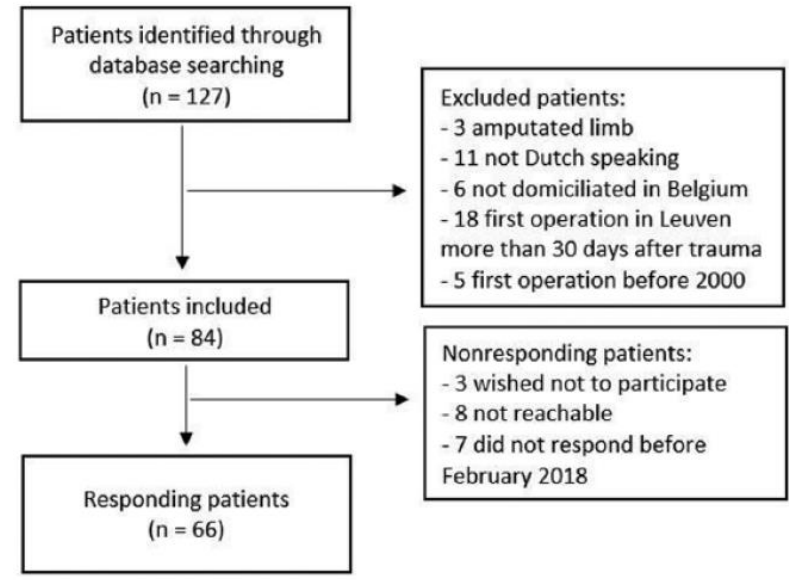

Figure 1. Inclusion process and responding patients.

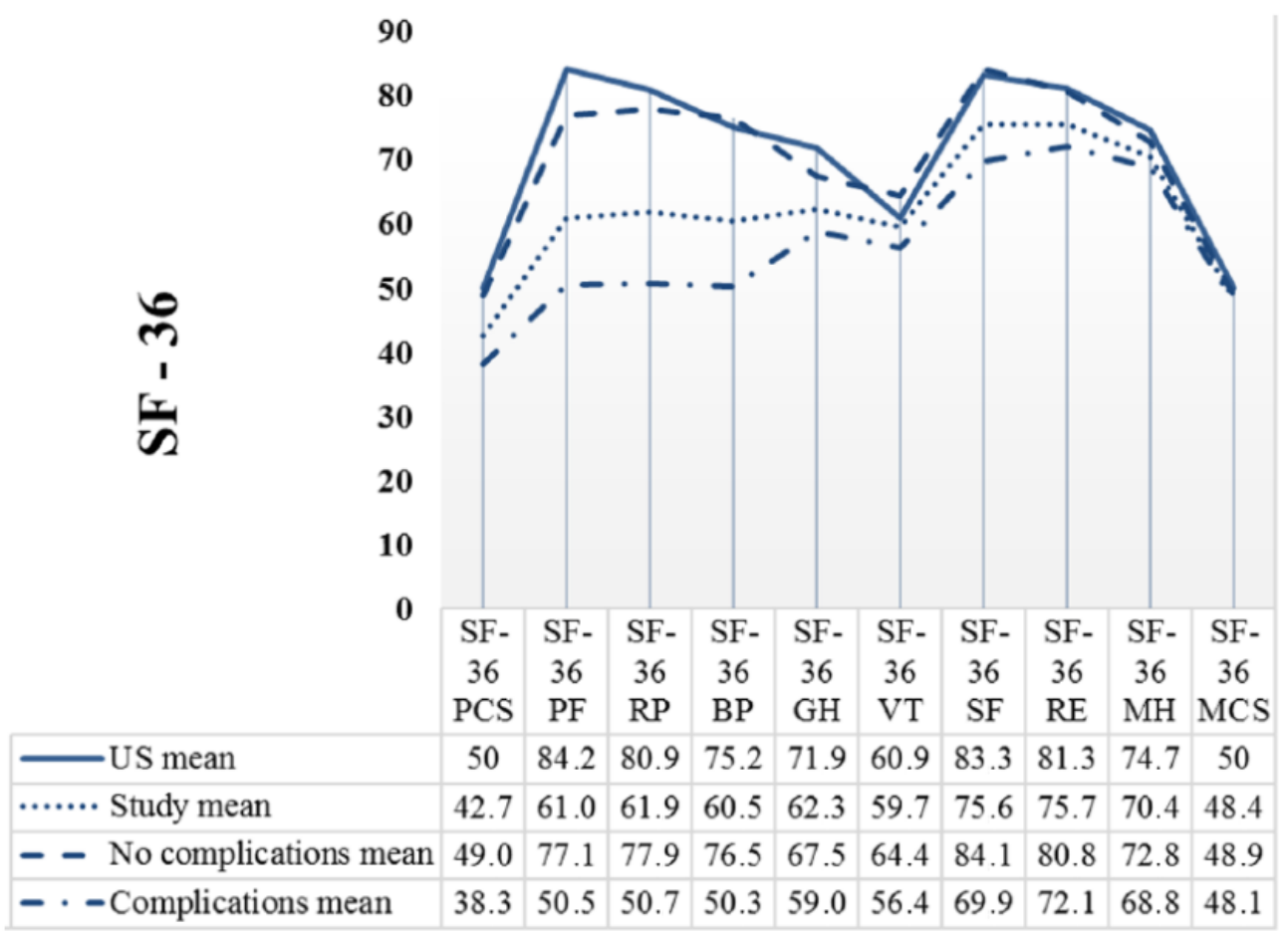

Figure 2. General health status. Mean SF-36 subscale and component summary scores are displayed for responding patients, and the US general population. The subscale scores are ordered according to their contribution to the PCS (left) and the MCS (right) scores. US mean values are derived from Ware et al.36 BP, bodily pain; GH, general health; MCS, Mental Component Summary; MH, mental health; PCS, Physical Component Summary; PF, physical function; RE, role emotional; RP, role physical; SF, social function; SF-36, Short Form 36; US, United States; VT, vitality. 


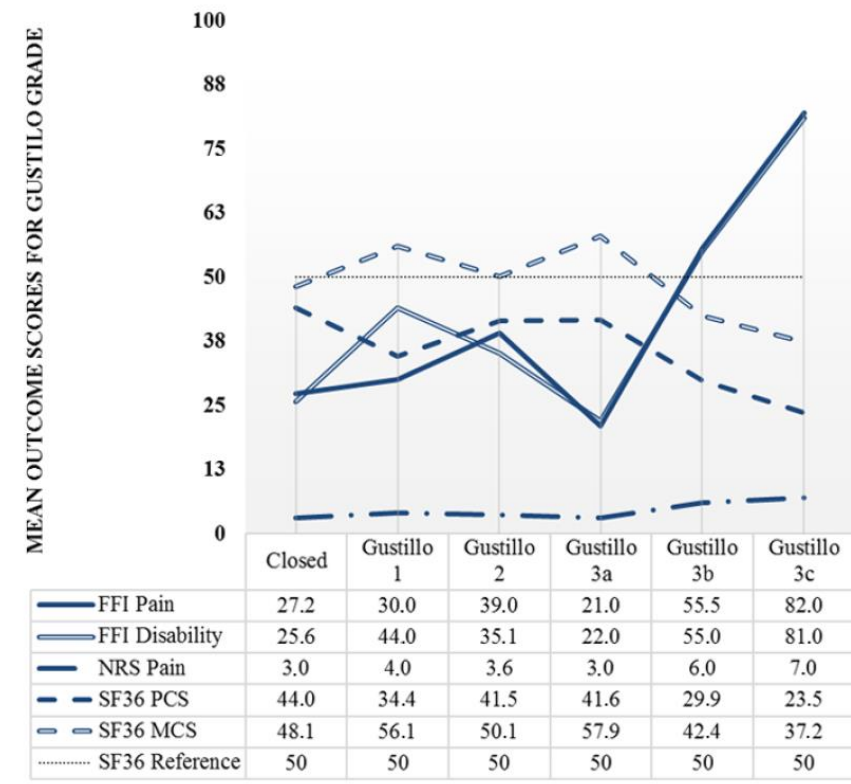

Figure 3. Gustilo grade outcome scores. The mean outcome scores for each Gustilo grade are displayed for all talus fractures in responding patients. Four patients had Gustilo grade 3 (1/65 Gustilo 3a, 2/65 Gustilo 3b, 1/65 Gustilo 3c). FFI, Foot Function Index; MCS, Mental Component Summary; NRS, numeric rating scale; PCS, Physical Component Summary; SF-36, Short Form 36.

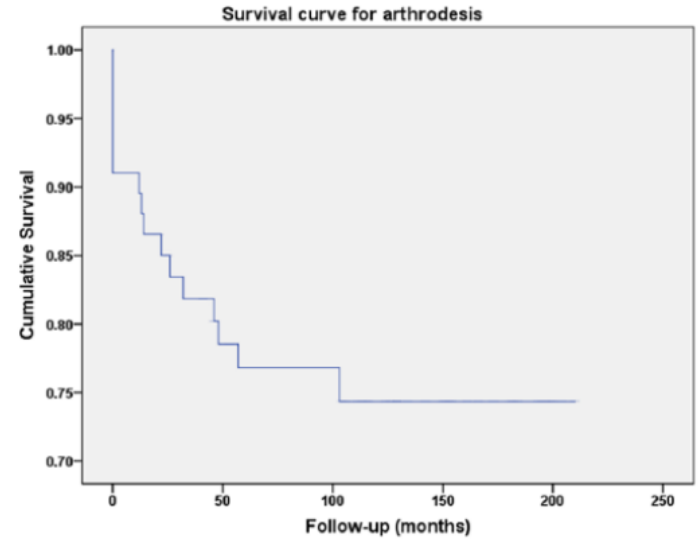

Figure 4. Survival curve with secondary arthrodesis as the event of interest. 


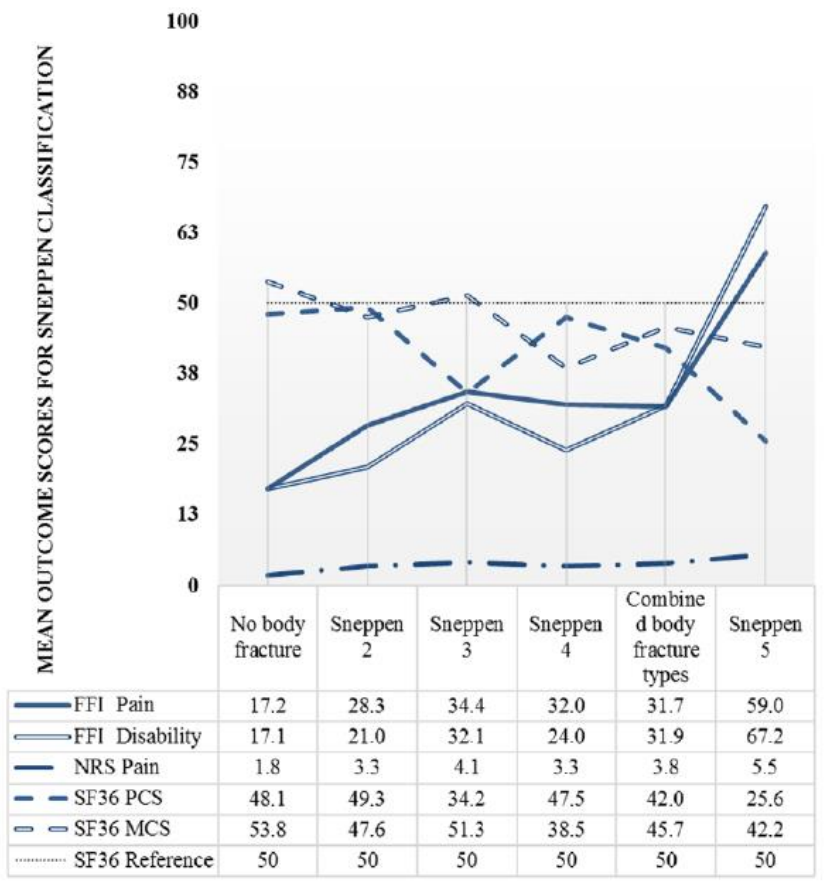

Figure 5. Talar body fractures outcome scores. The mean outcome scores for each type of body fracture are displayed for all talus fractures in responding patients. Body fractures are classified according to Sneppen et al.31 Combined body fracture types are Sneppen 2 and/or Sneppen 3 and/or Sneppen 4 fractures. FFI, Foot Function Index; MCS, Mental Component Summary; NRS, numeric rating scale; PCS, Physical Component Summary; SF-36, Short Form 36. 

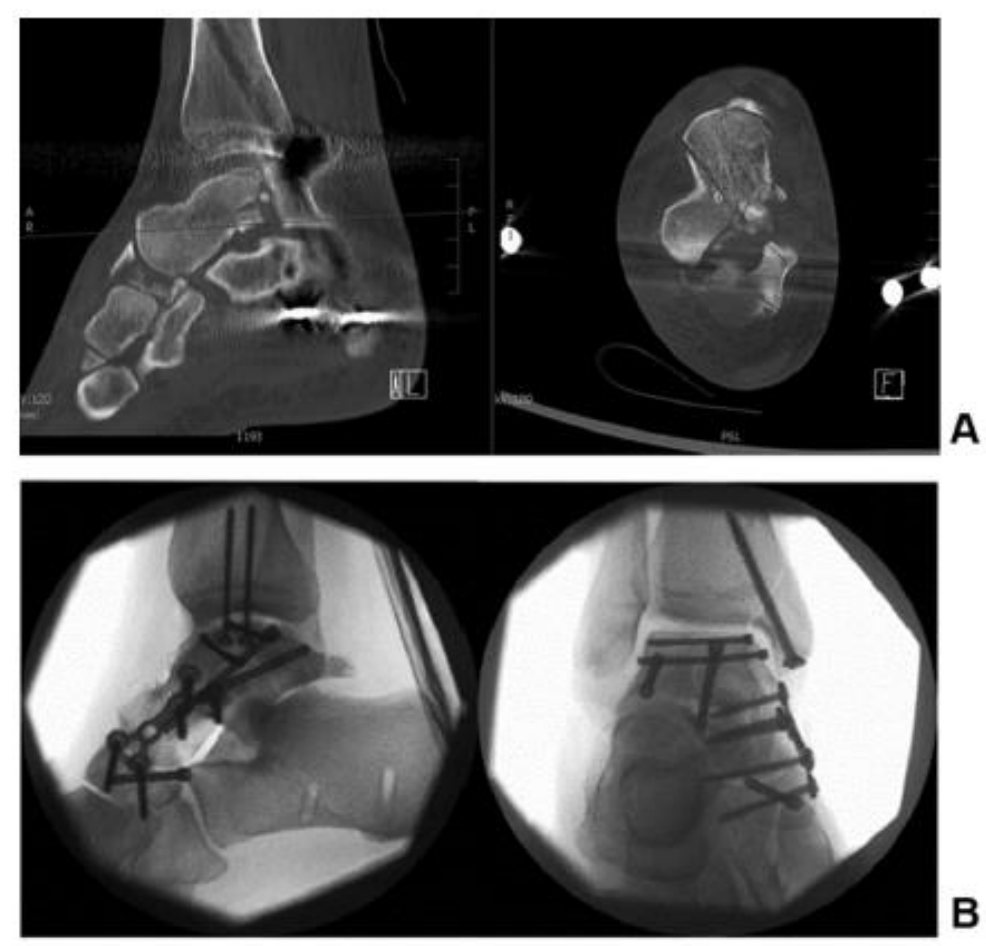

A
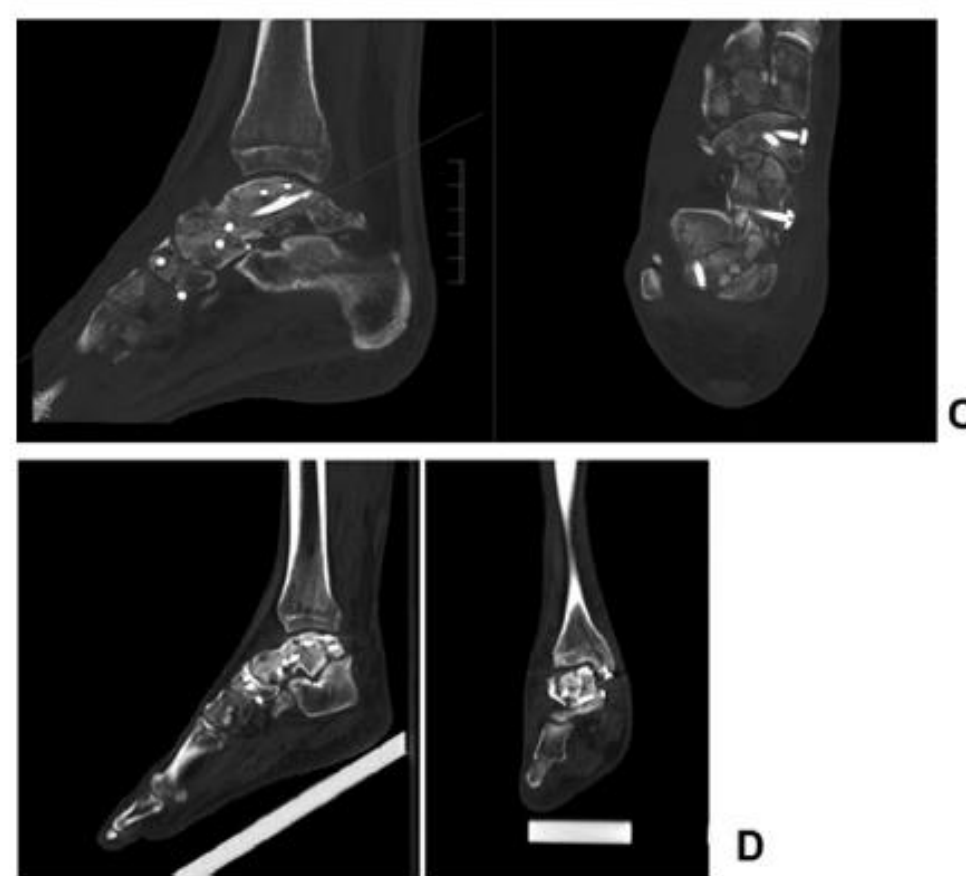

Figure 6. A 48-year-old patient had a talus fracture after fall from a height. The patient was transferred from regional hospital to our department after application of an external fixator. Preoperative CT showed a comminuted talonavicular subluxation fracture (A, left sagittal view, right axial view). The talus fracture was classified as Hawkins type 4 neck fracture and a Sneppen type 5 body fracture. The fractures were treated using a screw osteosynthesis (SOS) via an osteotomy of the medial malleolus, dual (posteromedial and anteromedial) approach; to re-create the length, the talonavicular joint was bridged ( $B$, left sagittal view, right coronal view). CT at 3 months showed adequate restoration of tibiotalar and talonavicular; however, there was marked subtalar incongruence (ie, articular damage and subluxation) (C, left sagittal view, right axial view). At 12 months postoperatively, there is a nonunion of the talus with signs of avascular necrosis, incongruence of both the tibiotalar and subtalar joint on SPECT-CT (D, left sagittal view, right coronal view). A pantalar arthrodesis will be planned in the near future. $\mathrm{CT}$, computed tomography; SPECT, single-photon emission computed tomography. 
Table 1. Demographic, Clinical, and Radiologic Characteristics.a

\begin{tabular}{|c|c|c|}
\hline Demographics & & \\
\hline $\begin{array}{l}\text { Age, } y, \text { mean (median) } \\
\text { Gender }\end{array}$ & $36.9(33.0)$ & \\
\hline Male & $65(77.4)$ & \\
\hline Female & $19(22.6)$ & \\
\hline ASA score & & $(i=4)$ \\
\hline 1 & $55(68.8)$ & \\
\hline 2 & $21(26.3)$ & \\
\hline 3 & $2(2.5)$ & \\
\hline 4 & $2(2.5)$ & \\
\hline BMI, mean (median) & $24.6(24.1)$ & $(i=2)$ \\
\hline Smoking & $23(27.4)$ & \\
\hline Daily alcohol use & $16(19.0)$ & \\
\hline Diabetes mellitus & $2(2.4)$ & \\
\hline Other CVRF & $17(20.2)$ & \\
\hline Fracture type & & \\
\hline Body fracture & $59(70.2)$ & $(i=1)$ \\
\hline Neck fracture & $35(41.7)$ & $(i=1)$ \\
\hline Head fracture & $13(15.5)$ & $(i=1)$ \\
\hline Associated fractures same foot or ankle & $51(60.0)$ & \\
\hline Open fracture & $16(18.8)$ & \\
\hline Gustilo 11 (1.2) & $1(1.2)$ & \\
\hline Gustilo 2 & $9(10.6)$ & \\
\hline Gustilo 3a & $2(2.4)$ & \\
\hline Gustilo 3b & $3(3.5)$ & \\
\hline Gustilo 3c & $1(1.2)$ & \\
\hline Time of treatment & & \\
\hline Early surgery & $13(15.5)$ & $(i=1)$ \\
\hline Delayed surgery & $54(64.3)$ & $(i=1)$ \\
\hline $\begin{array}{l}\text { Delayed-staged surgery } \\
\text { Delayed(-staged) time, d, mean } \\
\text { (median) }\end{array}$ & $\begin{array}{l}17(20.2) \\
8.6(5.0)\end{array}$ & $\begin{array}{l}(i=1) \\
(i=1)\end{array}$ \\
\hline Type of definite surgery & & \\
\hline SOS & $46(54.1)$ & \\
\hline PSOS & $9(10.6)$ & \\
\hline K-wiring & $15(17.6)$ & \\
\hline CREF & $7(8.2)$ & \\
\hline Primary arthrodesis & $8(9.4)$ & \\
\hline Talus transplant & $1(1.2)$ & \\
\hline Operative approach & & \\
\hline Anterior & $1(1.2)$ & \\
\hline
\end{tabular}


Table 1. (continued)

\begin{tabular}{|c|c|}
\hline Anteromedial & $44(51.8)$ \\
\hline Anterolateral & $33(38.8)$ \\
\hline Posteromedial & $14(16.5)$ \\
\hline Posterolateral & $10(11.8)$ \\
\hline Dual approach & $16(18.8)$ \\
\hline Medial malleolus osteotomy & $6(7.1)$ \\
\hline Lateral malleolus osteotomy & $1(1.2)$ \\
\hline Postoperative complication rate & $48(56.5)$ \\
\hline Operative site infection & $4(4.7)$ \\
\hline Nonunion & $15(24.2)$ \\
\hline Intra-articular incongruence & $18(22.8)$ \\
\hline AVN & 11 (12.9) \\
\hline Osteoarthritis & $36(42.4)$ \\
\hline Ankle osteoarthritis & $18(21.2)$ \\
\hline Other peritalar osteoarthritis & $29(34.1)$ \\
\hline Other postoperative complications & $8(9.4)$ \\
\hline Reintervention rate & 39 (45.9) \\
\hline Material removal & $26(30.6)$ \\
\hline Secondary arthrodesis & $12(14.1)$ \\
\hline Other reintervention & $12(14.1)$ \\
\hline
\end{tabular}

Abbreviations: ASA, American Society of Anesthesiologists; AVN, avascular necrosis; BMI, body mass index; CREF, closed reduction and external fixation; CVRF, cardiovascular risk factors; PSOS, plate and screw osteosynthesis; SOS, screw osteosynthesis. aContinuous parameters are expressed as mean (median) values; the rest are $n(\%)$. Demographic percentages are displayed per total patients $(n=84-i)$. All other percentages are displayed per total talus fractures $(n=85-i)$, with $i=$ the number of missing data.

Table 2. Outcome Measures.a

\begin{tabular}{|c|c|c|}
\hline FFI Total & 29.43 & \\
\hline FFI Pain score & 30.22 & \\
\hline FFI Disability score & 28.67 & \\
\hline NRS Pain & 3.20 & $(i=3)$ \\
\hline SF-36 & & $(i=4)$ \\
\hline PCS & 42.71 & \\
\hline MCS & 48.29 & \\
\hline Return to daily activity, $\mathrm{n}(\%)$ & 39 (59.1) & \\
\hline
\end{tabular}

Abbreviations: FFI, Foot Function Index; MCS, Mental Component Summary; NRS, numeric rating scale; PCS, Physical Component Summary; SF36, Short Form 36. aContinuous parameters are expressed as mean values. Percentages are displayed per total esponding patients $(n=66-i)$, with $i=$ the number of missing data. 
Table 3. Correlation Analysis. ${ }^{a}$

\begin{tabular}{|c|c|c|c|c|c|c|}
\hline & FFI Pain & $\begin{array}{c}\text { FFI } \\
\text { Disability }\end{array}$ & NRS Pain & $\begin{array}{l}\text { SF-36 } \\
\text { PCS }\end{array}$ & $\begin{array}{l}\text { SF-36 } \\
\text { MCS }\end{array}$ & $\begin{array}{c}\text { Return to Daily } \\
\text { Activity }\end{array}$ \\
\hline \multicolumn{7}{|l|}{ Demographics } \\
\hline Age $^{+}$ & 0.007 & 0.036 & 0.001 & 0.002 & 0.001 & 0.057 \\
\hline Male gender & 0.002 & 0.004 & 0.025 & 0.003 & 0.013 & 0.002 \\
\hline ASA & $0.062^{*}$ & 0.042 & $0.113^{* *}$ & 0.016 & 0.010 & 0.003 \\
\hline CVRF & $<0.001$ & 0.002 & 0.001 & 0.003 & 0.015 & 0.019 \\
\hline $\mathrm{BMI}^{+}$ & 0.032 & 0.033 & 0.019 & $0.099^{*}$ & 0.004 & $<0.001$ \\
\hline Smoking & 0.004 & 0.012 & 0.003 & 0.009 & $<0.001$ & 0.018 \\
\hline Daily alcohol & 0.011 & 0.009 & 0.013 & 0.003 & $<0.001$ & 0.024 \\
\hline Diabetes & 0.007 & 0.001 & 0.006 & $<0.001$ & 0.021 & 0.043 \\
\hline Other CVRF & 0.001 & 0.015 & 0.007 & 0.033 & 0.014 & 0.003 \\
\hline \multicolumn{7}{|l|}{ Fracture type } \\
\hline Body fracture & $0.131^{* *}$ & $0.095^{*}$ & $0.133^{* *}$ & $0.072^{*}$ & $0.154^{* *}$ & 0.007 \\
\hline Neck fracture & 0.012 & 0.019 & 0.015 & 0.015 & 0.024 & 0.003 \\
\hline Head fracture & 0.050 & 0.024 & 0.051 & 0.060 & 0.030 & $0.095^{*}$ \\
\hline Associated fractures same foot or ankle & $0.006^{*}$ & 0.054 & $0.094^{*}$ & 0.005 & 0.002 & 0.050 \\
\hline Open fracture & 0.045 & $0.064^{*}$ & 0.037 & 0.052 & 0.030 & $0.114^{*}$ \\
\hline Gustillo grade & 0.049 & $0.070^{*}$ & 0.042 & 0.059 & 0.023 & $0.120^{*}$ \\
\hline \multicolumn{7}{|l|}{ Time of treatment } \\
\hline Early surgery & 0.024 & 0.020 & 0.007 & 0.045 & 0.031 & $0.153^{* *}$ \\
\hline Delayed surgery & $0.083^{*}$ & $0.134^{* *}$ & 0.041 & $0.200^{* * *}$ & $<0.001$ & $0.248^{* * *}$ \\
\hline Delayed-staged surgery & 0.040 & $0.092^{*}$ & 0.028 & $0.111^{* *}$ & 0.026 & 0.062 \\
\hline Delayed(-staged) time ${ }^{+}$ & $<0.001$ & 0.013 & 0.001 & 0.015 & 0.008 & $<0.001$ \\
\hline \multicolumn{7}{|l|}{ Type of definite surgery } \\
\hline SOS & $0.062^{*}$ & $0.110^{* *}$ & $0.082^{*}$ & $0.144^{* *}$ & 0.004 & $0.084^{*}$ \\
\hline PSOS & 0.025 & 0.000 & 0.009 & $<0.001$ & 0.002 & 0.034 \\
\hline K-wiring & $0.067^{*}$ & 0.045 & $0.089^{*}$ & 0.058 & 0.011 & 0.013 \\
\hline CREF & 0.020 & 0.008 & 0.002 & $<0.001$ & 0.001 & 0.039 \\
\hline Prim. arthrodesis & 0.012 & 0.046 & 0.031 & $0.130^{* *}$ & 0.027 & $0.105^{*}$ \\
\hline \multicolumn{7}{|l|}{ Operative approach } \\
\hline Anteromedial & 0.015 & 0.004 & 0.034 & 0.046 & 0.002 & $0.131^{*}$ \\
\hline Anterolateral & 0.008 & 0.017 & 0.008 & 0.000 & 0.038 & 0.039 \\
\hline Posteromedial & 0.002 & 0.018 & 0.001 & 0.024 & $<0.001$ & 0.024 \\
\hline Posterolateral & 0.052 & 0.017 & $0.080^{*}$ & 0.043 & 0.051 & 0.001 \\
\hline Dual approach & 0.030 & $0.100^{*}$ & 0.023 & $0.096^{*}$ & 0.037 & $0.179^{* *}$ \\
\hline Medial malleolus osteotomy & 0.041 & 0.044 & 0.004 & 0.017 & 0.027 & 0.018 \\
\hline \multicolumn{7}{|l|}{ Postoperative complications } \\
\hline Postoperative complication & $0.248^{* * *}$ & $0.244^{* * *}$ & $0.296^{* * *}$ & $0.181^{* * *}$ & $<0.001$ & $0.223^{* * *}$ \\
\hline Operative site infection & 0.017 & 0.025 & 0.018 & 0.024 & 0.012 & $0.114^{*}$ \\
\hline Articular incongruence & $0.081^{*}$ & $0.076^{*}$ & $0.112^{* *}$ & $0.110^{* *}$ & 0.016 & 0.041 \\
\hline Nonunion & $0.078^{*}$ & $0.097^{*}$ & $0.104^{*}$ & 0.022 & 0.001 & 0.072 \\
\hline AVN & 0.044 & $0.070^{*}$ & 0.038 & 0.052 & 0.025 & 0.062 \\
\hline Osteoarthritis & $0.262^{* * *}$ & $0.236^{* * *}$ & $0.231^{* * *}$ & $0.228^{* * *}$ & 0.021 & $0.208^{* * *}$ \\
\hline Ankle osteoarthritis & $0.135^{* *}$ & $0.164^{* * *}$ & $0.063^{*}$ & $0.174^{* * *}$ & 0.003 & $0.175^{* *}$ \\
\hline Other peritalar ostoarthritis & $0.202^{* * *}$ & $0.180^{* * *}$ & $0.200^{* * *}$ & $0.084^{*}$ & 0.030 & $0.128^{*}$ \\
\hline Other complications & 0.001 & 0.006 & $<0.001$ & 0.002 & 0.007 & 0.001 \\
\hline \multicolumn{7}{|l|}{ Reinterventions } \\
\hline Reintervention & 0.032 & 0.025 & 0.025 & 0.047 & 0.002 & 0.036 \\
\hline Number of reinterventions ${ }^{+}$ & 0.026 & 0.026 & 0.020 & 0.052 & 0.001 & $0.109^{*}$ \\
\hline
\end{tabular}

Abbreviations: ASA, American Society of Anesthesiologists; AVN, avascular necrosis; BMI, body mass index; CREF, closed reduction and external fixation; CVRF, cardiovascular risk factors; FFI, Foot Function Index; MCS, Mental Component Summary; NRS, numeric rating scale; PCS, Physical Component Summary; PSOS, plate and screw osteosynthesis; SF-36, Short Form 36; SOS, screw osteosynthesis. ${ }^{\mathrm{a} C o r r e l a t i o n s}$ were noted as $R^{2}$ values. Pearson correlation was used whenever both the outcome parameter and the predicting parameter are continuous. Outcome parameters are all continuous except return to daily activity. The predicting parameters are marked ${ }^{+}$if they are continuous. Spearman correlation was used whenever the predicting parameter is not continuous. For return to daily activity, the logistic regression with Nagelkerke $R^{2}$ was used. If marked ${ }^{*},{ }^{* *}$, or ${ }^{* * *}$, the correlation model is significant at the $0.05,0.01$, or 0.001 level, respectively. Underscored are all $R^{2}$ values of those characteristics that lead to a better outcome when present (for binominal parameters) or with increasing number (for multinominal or continuous parameters). 

Long-term outcome after operative management of talus fractures: what have we learned? - ADDENDA

\section{TABLE OF CONTENTS}

Addendum I: Hawkins classification___ p.2

Addendum II: Sneppen classification__ p.2

Addendum III: Supplementary tables__ p.3

Supplementary table $1 \ldots$ p.3

Supplementary table $2 \ldots$ p.4

Supplementary table $3 \_$p.5

Supplementary table $4 \_$p.6

Supplementary table 5__p.7

Supplementary table 6__p.10

Supplementary table $7 \_$p.11

Supplementary table 8_p.12

Supplementary table 9

Addendum IV: Questionnaire___ p.13 


\section{ADDENDUM I: HAWKINS CLASSIFICATION MODIFIED BY CANALE AND KELLY 5}

Type 1: Undisplaced talar neck fracture

Type 2: Displaced talar neck fracture with subluxation or dislocation of the subtalar joint

Type 3: Displaced talar neck fracture with subluxation or dislocation of the subtalar and ankle joints

Type 4: Displaced talar neck fracture with subluxation or dislocation of the subtalar, ankle and talonavicular joints.

\section{ADDENDUM II: SNEPPEN CLASSIFICATION ${ }^{31}$}

Type 1: Transchondral talar body fracture

Type 2: Sagittal, coronal or horizontal talar body fracture

Type 3: Processus posterior fracture of the talus

Type 4: Processus lateralis fracture of the talus

Type 5: Crush fracture of the talar body 
Supplementary table 1. Demographic, clinical and radiological characteristics

\begin{tabular}{|c|c|c|c|}
\hline & All patients & Responders & $\begin{array}{l}\text { Responders VS } \\
\text { Nonresponders }\end{array}$ \\
\hline \multicolumn{4}{|l|}{ Demographics } \\
\hline Age (years) & $36.86(33.00)$ & $39.46(35.50)$ & 0.106 (MWU) \\
\hline Gender & & & $0.060(\mathrm{FE})$ \\
\hline Male & 65 (77.4\%) & $48(72.7 \%)$ & \\
\hline Female & $19(22.6 \%)$ & $18(27.3 \%)$ & \\
\hline ASA-score & & & $0.039\left(\mathrm{Chi}^{2}\right)$ * \\
\hline 1 & $55(68.8 \%)$ & 45 (71.4\%) & $P>0.05$ \\
\hline 2 & $21(26.3 \%)$ & $16(25.4 \%)$ & $P>0.05$ \\
\hline 3 & $2(2.5 \%)$ & $0(0 \%)$ & $P<0.05^{*}$ \\
\hline 4 & $2(2.5 \%)$ & $2(3.2 \%)$ & $P>0.05$ \\
\hline $\mathrm{BMI}\left(\mathrm{kg} / \mathrm{m}^{2}\right)$ & $24.59(24.10)$ & $24.67(24.20)$ & 0.391 (MWU) \\
\hline Smoking & $23(27.4 \%)$ & $18(27.3 \%)$ & 1.000 (FE) \\
\hline Daily alcohol use & $16(19.0 \%)$ & $12(18.2 \%)$ & 0.739 (FE) \\
\hline Diabetes mellitus & $2(2.4 \%)$ & $2(3.0 \%)$ & $1.000(\mathrm{FE})$ \\
\hline Other CVRF & $17(20.2 \%)$ & $16(24.2 \%)$ & $0.104(\mathrm{FE})$ \\
\hline \multicolumn{4}{|l|}{ Fracture type } \\
\hline Body fracture & 59 (70.2\%) & 47 (71.2\%) & $0.708\left(\mathrm{Chi}^{2}\right)$ \\
\hline Neck fracture & $35(41.7 \%)$ & $30(45.5 \%)$ & $0.178\left(\mathrm{Chi}^{2}\right)$ \\
\hline Head fracture & $13(15.5 \%)$ & $10(15.2 \%)$ & $1.000(\mathrm{FE})$ \\
\hline $\begin{array}{l}\text { Associated fractures same foot } \\
\text { or ankle }\end{array}$ & $51(60.0 \%)$ & $40(59.7 \%)$ & $0.914\left(\mathrm{Chi}^{2}\right)$ \\
\hline Open fracture & $16(18.8 \%)$ & $13(19.4 \%)$ & $1.000(\mathrm{FE})$ \\
\hline Gustilo 1 & $1(1.2 \%)$ & $1(1.5 \%)$ & $0.798\left(\mathrm{Chi}^{2}\right)$ \\
\hline Gustilo 2 & $9(10.6 \%)$ & $8(11.9 \%)$ & \\
\hline Gustilo 3a & $\overline{2(2.4 \%)}$ & $\overline{1(1.5 \%)}$ & \\
\hline$\overline{\text { Gustilo 3b }}$ & $\overline{3(3.5 \%)}$ & $\overline{2(3.0 \%)}$ & \\
\hline Gustilo 3c & $1(1.2 \%)$ & $1(1.5 \%)$ & \\
\hline \multicolumn{4}{|l|}{ Time of treatment } \\
\hline Early surgery & $13(15.5 \%)$ & $10(15.2 \%)$ & $1.000(\mathrm{FE})$ \\
\hline Delayed surgery & $54(64.3 \%)$ & $41(62.1 \%)$ & $0.428\left(\mathrm{Chi}^{2}\right)$ \\
\hline Delayed-staged surgery & $17(20.2 \%)$ & $15(22.7 \%)$ & $0.343(\mathrm{FE})$ \\
\hline $\begin{array}{l}\text { Delayed(-staged) time } \\
\text { (days) }\end{array}$ & $8.56(5.00)$ & $9.22(6.00)$ & 0.149 (MWU) \\
\hline \multicolumn{4}{|l|}{ Type of definite surgery } \\
\hline sos & $46(54.1 \%)$ & $36(53.7 \%)$ & $0.890\left(\mathrm{Chi}^{2}\right)$ \\
\hline PSOS & $9(10.6 \%)$ & $7(10.4 \%)$ & $1.000(\mathrm{FE})$ \\
\hline K-wiring & $15(17.6 \%)$ & $12(17.9 \%)$ & $1.000(\mathrm{FE})$ \\
\hline CREF & $7(8.2 \%)$ & $6(9.0 \%)$ & $1.000(\mathrm{FE})$ \\
\hline Arthrodesis & $8(9.4 \%)$ & $6(9.0 \%)$ & $0.675(\mathrm{FE})$ \\
\hline Talar transplant & $1(1.2 \%)$ & $1(1.5 \%)$ & $1.000(\mathrm{FE})$ \\
\hline Surgical approach & & & $0.977\left(\mathrm{Chi}^{2}\right)$ \\
\hline Anterior & $1(1.2 \%)$ & $1(1.2 \%)$ & \\
\hline Anteromedial & $\underline{44(51.8 \%)}$ & $35(41.2 \%)$ & \\
\hline Anterolateral & $33(38.8 \%)$ & $26(30.6 \%)$ & \\
\hline Posteromedial & $14(16.5 \%)$ & $12(14.1 \%)$ & \\
\hline Posterolateral & $10(11.8 \%)$ & $8(9.4 \%)$ & \\
\hline Dual approach & $16(18.8 \%)$ & $14(20.9 \%)$ & $\underline{0.504(\mathrm{FE})}$ \\
\hline Medial malleolus osteotomy & $\underline{6(7.1 \%)}$ & $5(7.5 \%)$ & $\underline{\underline{0.148(\mathrm{FE})}}$ \\
\hline Lateral malleolus osteotomy & $1(1.2 \%)$ & $0(0 \%)$ & \\
\hline
\end{tabular}




\begin{tabular}{|c|c|c|c|}
\hline $\begin{array}{l}\text { Postoperative complication } \\
\text { rate }\end{array}$ & 48 (56.5\%) & $41(61.2 \%)$ & $0.112\left(\mathrm{Chi}^{2}\right)$ \\
\hline Surgical site infection & $4(4.7 \%)$ & $3(4.5 \%)$ & $1.000(\mathrm{FE})$ \\
\hline Nonunion & $15(24.2 \%)$ & $14(27.5 \%)$ & $0.268(\mathrm{FE})$ \\
\hline Intra-articular incongruence & $18(22.8 \%)$ & $14(21.2 \%)$ & 0.479 (FE) \\
\hline AVN & $11(12.9 \%)$ & $9(13.4 \%)$ & $1.000(\mathrm{FE})$ \\
\hline Osteoarthritis & $36(42.4 \%)$ & $30(44.8 \%)$ & $0.383\left(\mathrm{Chi}^{2}\right)$ \\
\hline Ankle osteoarthritis & $7(8.2 \%)$ & $6(9.0 \%)$ & 0.850 (Ch \\
\hline Other peritalar & $18(21.2 \%)$ & $15(22.4 \%)$ & \\
\hline osteoarthritis & & & \\
\hline $\begin{array}{l}\text { Both ankle and other } \\
\text { peritalar ostoarthritis }\end{array}$ & $11(12.9 \%)$ & $9(13.4 \%)$ & \\
\hline $\begin{array}{l}\text { Other postoperative } \\
\text { complications }\end{array}$ & $8(9.4 \%)$ & 7 (10.4\%) & 1.000 (FE) \\
\hline Reintervention rate & $39(45.9 \%)$ & $33(49.3 \%)$ & $0.229\left(\mathrm{Chi}^{2}\right)$ \\
\hline Material removal & $26(30.6 \%)$ & $21(31.3 \%)$ & $0.771\left(\mathrm{Chi}^{2}\right)$ \\
\hline Arthrodesis & $12(14.1 \%)$ & $11(16.4 \%)$ & $0.446(\mathrm{FE})$ \\
\hline Other reintervention & $12(14.1 \%)$ & $11(16.4 \%)$ & 0.446 (FE) \\
\hline
\end{tabular}

Continuous parameters are expressed as mean (median) values. Demographic percentages are displayed per total patients (all patients, $n=84-i$ and responders, $n=66-i$ ). All other percentages are displayed per total talus fractures (all patients, $n=85-i$ and responders, $n=$ $67-i)$ With $\mathrm{i}=$ the number of missing data. Differences between responders and nonresponders for these values were displayed as: p-value (statistical test). Statistically significant values are marked *

Abbreviations: ASA, American Society of Anesthesiologists; BMI, Body Mass Index; CVRF, cardiovascular risk factors; SOS, screw osteosynthesis; PSOS, plate and screw osteosynthesis; CREF, closed reduction and external fixation; AVN, avascular necrosis; MWU, Mann Withney U test; $\mathrm{Chi}^{2}$, Pearson Chi-Square test; FE, Fisher's Exact test.

Supplementary table 2. Median outcome scores

\begin{tabular}{ll}
\hline FFI Total & $23.0(10.0-48.0)$ \\
FFI Pain & $29.0(11.0-46.0)$ \\
FFI Disability & $22.0(6.0-47.0)$ \\
NRS Pain & $3.0(1.0-5.0)$ \\
SF-36 & $44.0(32.5-52.9)$ \\
PCS & $52.0(42.1-55.6)$ \\
MCS & $39(60.0 \%)$ \\
Return to daily activity & Continuous parameters are expressed as median values with \\
their respective interquartile range. Percentages are displayed \\
per total responding patients (n=66-i). With $\mathrm{i}=$ the number of \\
missing data. Abbreviations: FFI, Foot Function Index; NRS, \\
Numeric Rating Scale; SF-36, Short Form 36; PCS, Physical \\
Component Summary; MCS, Mental Component Summary.
\end{tabular}


Supplementary table 3. Median outcome scores for Sneppen classification

\begin{tabular}{|c|c|c|c|c|c|}
\hline & $\begin{array}{l}\text { FFI } \\
\text { Pain }\end{array}$ & $\begin{array}{l}\text { FFI } \\
\text { Disability }\end{array}$ & $\begin{array}{l}\text { NRS } \\
\text { Pain }\end{array}$ & $\begin{array}{l}\text { SF36 } \\
\text { PCS }\end{array}$ & $\begin{array}{l}\text { SF36 } \\
\text { MCS }\end{array}$ \\
\hline Sneppen2 & $\begin{array}{l}14.0 \\
(4.0-61.0)\end{array}$ & $\begin{array}{l}9.0 \\
(0.0-34.0)\end{array}$ & $\begin{array}{l}4.0 \\
(0.0-7.0)\end{array}$ & $\begin{array}{l}52.5 \\
(44.7-58.8)\end{array}$ & $\begin{array}{l}51.8 \\
(44.7-52.1)\end{array}$ \\
\hline Sneppen 3 & $\begin{array}{l}32.5 \\
(26.0-45.3)\end{array}$ & $\begin{array}{l}27.0 \\
(22.8-43.8)\end{array}$ & $\begin{array}{l}5.0 \\
(3.0-5.0)\end{array}$ & $\begin{array}{l}33.0 \\
(26.7-40.6)\end{array}$ & $\begin{array}{l}52.5 \\
(49.6-56.6)\end{array}$ \\
\hline Sneppen 4 & $\begin{array}{l}21.0 \\
(14.0-57.0)\end{array}$ & $\begin{array}{l}16.0 \\
(3.0-50.0)\end{array}$ & $\begin{array}{l}3.0 \\
(0.0-7.0)\end{array}$ & $\begin{array}{l}49.9 \\
(32.5-57.4)\end{array}$ & $\frac{37.4}{(25.4-53.7)}$ \\
\hline Combined FX & $\begin{array}{l}31.0 \\
(10.0-48.0)\end{array}$ & $\begin{array}{l}29.5 \\
(9.0-54.5)\end{array}$ & $\begin{array}{l}3.0 \\
(2.0-7.0)\end{array}$ & $\begin{array}{l}42.0 \\
(28.4-52.9)\end{array}$ & $\begin{array}{l}46.6 \\
(35.5-55.5)\end{array}$ \\
\hline Sneppen 5 & $\frac{64.5}{(38.5-76.8)}$ & $\frac{76.5}{(47.5-83.5)}$ & $\frac{6.0}{(3.5-7.0)}$ & $\frac{23.5}{(19.3-33.0)}$ & $\begin{array}{l}42.1 \\
(32.8-51.6)\end{array}$ \\
\hline $\begin{array}{l}\text { No body } \\
\text { fracture }\end{array}$ & $\begin{array}{l}11.0 \\
(0.0-30.0)\end{array}$ & $\begin{array}{l}13.0 \\
(0.0-34.0)\end{array}$ & $\begin{array}{l}1.0 \\
(0.0-4.0)\end{array}$ & $\begin{array}{l}47.5 \\
(42.6-56.5)\end{array}$ & $\begin{array}{l}55.5 \\
(52.5-58.2)\end{array}$ \\
\hline \multicolumn{6}{|c|}{$\begin{array}{l}\text { Numbers are expressed as median values with their respective interquartile } \\
\text { range. Worst scorings are underlined. Abbreviations: FFI, Foot Function Index; } \\
\text { NRS, Numeric Rating Scale; SF-36, Short Form 36; PCS, Physical Component } \\
\text { Summary; MCS, Mental Component Summary. Combined body fracture types } \\
\text { are Sneppen } 2 \text { and/or Sneppen } 3 \text { and/or Sneppen } 4 \text { fractures. }\end{array}$} \\
\hline
\end{tabular}


Supplementary table 4. Foot Function Index; descriptives for all questions

\section{Pain}

B1 At its worst

B2 Before you get up in the morning

B3 When you walked without shoes

B4 When you stood without shoes

B5 When you walked wearing shoes

B6 When you stood wearing shoes

$B 7^{*}$ When you walked wearing custom shoe inserts

B8* When you stood wearing custom

shoe inserts

B9 At the end of the day

Disability

C1 Walking around inside your house C2 Walking outside on uneven ground

C3 Walking $500 \mathrm{~m}$ or more

C4 Climbing stairs

C5 Descending stairs

C6 Standing on tip toes

C7 Getting out of a chair

C8 Walking up or down a curb

C9* Walking fast

$\begin{array}{llll}\text { No pain } & \text { Some pain } & & \text { Considerable } \\ & & & \text { pain } \\ 33(18.2 \%) & 19(28.8 \%) & 16(24.2 \%) \\ 17(25.8 \%) & 18(27.3 \%) & 7(10.6 \%) \\ 27(40.9 \%) & 16(24.2 \%) & 13(19.7 \%) \\ 20(30.3 \%) & 23(34.8 \%) & 12(18.2 \%) \\ 30(45.5 \%) & 22(33.3 \%) & 9(13.6 \%) \\ 10(15.2 \%) & 11(16.7 \%) & 6(9.1 \%) \\ 12(18.2 \%) & 13(19.7 \%) & 5(7.6 \%) \\ 17(25.8 \%) & 20(30.3 \%) & 11(16.7 \%)\end{array}$

No

\begin{tabular}{lll}
$\frac{\text { No }}{\text { difficulty }}$ & $\frac{\text { Some }}{\text { difficulty }}$ & $\frac{\text { Considerable }}{\text { difficulty }}$ \\
\hline $34(51.5 \%)$ & $\frac{1}{19(28.8 \%)}$ & $10(15.2 \%)$ \\
$15(22.7 \%)$ & $22(33.3 \%)$ & $16(24.2 \%)$ \\
$27(40.9 \%)$ & $13(19.7 \%)$ & $13(19.7 \%)$ \\
$26(39.4 \%)$ & $19(28.8 \%)$ & $9(13.6 \%)$ \\
$23(34.8 \%)$ & $18(27.3 \%)$ & $10(15.2 \%)$ \\
$21(31.8 \%)$ & $14(21.2 \%)$ & $8(12.1 \%)$ \\
$39(59.1 \%)$ & $10(15.2 \%)$ & $10(15.2 \%)$ \\
$32(48.5 \%)$ & $19(28.8 \%)$ & $9(13.6 \%)$ \\
$10(15.2 \%)$ & $11(16.7 \%)$ & $9(13.6 \%)$
\end{tabular}

Severe pain Unbearable

pain

$14(21.2 \%) \quad 5(7.6 \%)$

$8(12.1 \%)$

$9(13.6 \%)$

$4(6.1 \%)$

$8(12.1 \%)$

$5(7.6 \%)$

$4(6.1 \%)$

$3(4.5 \%)$

$16(24.2 \%)$ 0

$3(4.5 \%)$

$2(3.0 \%)$

$1(1.5 \%)$

0

0

0

0

$\frac{\text { Severe }}{\text { difficulty }}$

$3(4.5 \%)$

$9(13.6 \%)$

$9(13.6 \%)$

$11(16.7 \%)$

$11(16.7 \%)$

$6(9.1 \%)$

$5(7.6 \%)$

$7(10.6 \%)$

Impossible

0

$4(6.1 \%)$

$5(7.6 \%)$

$3(4.5 \%)$

$4(6.1 \%)$

$10(15.2 \%)$

$1(1.5 \%)$

27 (40.9\%)

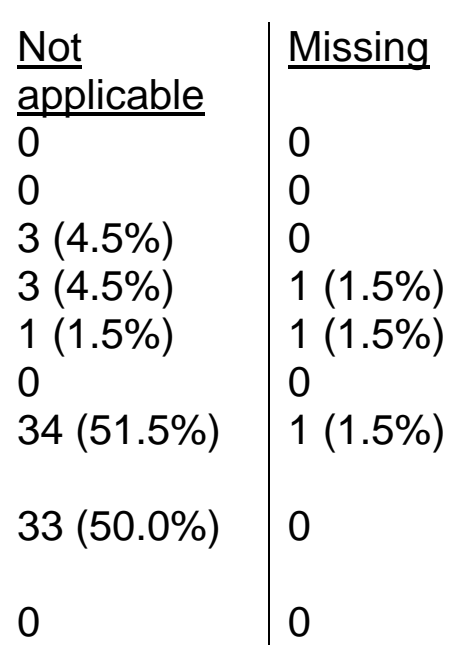

\begin{tabular}{l|l}
$\frac{\text { Not }}{\text { applicable }}$ & Missing \\
0 & 0 \\
0 & 0 \\
0 & 0 \\
0 & 0 \\
0 & 0 \\
$2(3.0 \%)$ & 0 \\
0 & 0 \\
$1(1.5 \%)$ & 0 \\
$2(3.0 \%)$ & 0
\end{tabular}

Percentages are displayed according to total responders $(n=66) .{ }^{*}$ As advised by Kuyvenhoven et al., these values were not considered when computing the total FFI pain, FFI disability and FFI total scores. ${ }^{22}$ 
Supplementary tabel 5. SF36; descriptives for all questions

$\mathrm{GH} 1$ In general, would you say your health is:

HC 1 Compared with one year ago, how would you rate your health in general now?

$\begin{array}{ll}\frac{\text { Excellent }}{6(9.1 \%)} & \frac{\text { Very good }}{18(27.3 \%)} \\ \frac{\text { A lot better }}{5(7.6 \%)} & \frac{\text { A little better }}{9(13.6 \%)}\end{array}$

Does your health now limit you in following activities?

PF 1 During vigorous activities, such as running, lifting heavy objects, participating in strenuous sports.

PF 2 During moderate activities, such as moving 11 (16.7\%) 26 (39.4\%) a table, pushing a vacuum cleaner, cycling.

PF 3 Lifting or carrying groceries

PF 4 Climbing several flights of stairs

PF 5 Climbing one flight of stairs

PF 6 Bending over, kneeling, squatting

PF 7 Walking over 1 kilometer

PF 8 Walking a few hundred meters

PF 9 Walking around 100 meters

PF 10 Washing yourself or getting dressed

Has your physical health limited you last 4 weeks?

RP 1 Cut down the amount of time you spent on work or other activities

RP 2 Accomplished less than you would like RP 3 Were limited in the kind of work or other activities

RP 4 Had difficulty performing the work or other activities

\begin{tabular}{|c|c|c|}
\hline Good & Moderate & Bad \\
\hline 31 (47.0\%) & 11 (16.7\%) & 0 \\
\hline The same & A little & A lot worse \\
\hline 45 (68.2\%) & $\frac{\text { worse }}{7(10.6 \%)}$ & 0 \\
\hline
\end{tabular}

No

$\frac{\text { Yes }}{38(57.6 \%)} \quad \frac{\text { A little }}{21(31.8 \%)} \quad \frac{\text { No }}{6(9.1 \%)}$

$28(42.4 \%)$

$31(47.0 \%)$

$24(36.4 \%)$

$31(47.0 \%)$

$14(21.2 \%)$

$26(39.4 \%)$

$35(53.0 \%)$

$40(60.8 \%)$

$52(78.8 \%)$
Missing

0

Missing

0

Missing

$1(1.5 \%)$

$1(1.5 \%)$

0

$1(1.5 \%)$

$1(1.5 \%)$

$1(1.5 \%)$

$1(1.5 \%)$

$1(1.5 \%)$

$1(1.5 \%)$

0

Missing

$3(4.5 \%)$

$3(4.5 \%)$

$2(3.0 \%)$

$3(4.5 \%)$ 
Has your emotional health limited you last 4 weeks? (such as feeling depressed or anxious) $\mathrm{RE} 1$ Cut down the amount of time you spent on work or other activities

RE 2 Accomplished less than you would like

RE 3 Didn't do work or other activities as

carefully as usual

SF1 Did your emotional problems interfere with your normal social activities with family, friends, neighbours, or groups?

BP 1 How much bodily pain have you had during the past 4 weeks?

BP 2 During the past 4 weeks, how much did pain interfere with your normal work (including both work outside the home and housework)?

During the last 4 weeks, how often did you feel:

VT 1 canty

$\mathrm{MH} 1$ nervous

$\mathrm{MH} 2$ nothing could cheer you up

$\mathrm{MH} 3$ calm and relaxed

VT 2 energetic
Yes $\quad$ No

Missing

$12(18.2 \%) 50(75.8 \%)$

$4(6.1 \%)$

$21(31.8 \%) \quad 42(63.6 \%)$

$15(22.7 \%) \quad 48(72.7 \%)$

$3(4.5 \%)$

$3(4.5 \%)$

Totally not Slightly

$29(43.9 \%) \quad 22(33.3 \%)$

Quite

$\frac{\text { A lot }}{3(4.5 \%)} \quad \frac{\text { Very much }}{5(7.6 \%)}$

Missing

$5(7.6 \%)$

$3(4.5 \%)$

(5.6\%)

$2(3.0 \%)$

$\begin{array}{lllllll}\text { None } & \text { Very light } & \text { Light } & \text { Quite } & \text { Severe } & \underline{\text { Very }} & \text { Missing } \\ 10(15.2 \%) & 15(22.7 \%) & 13(19.7 \%) & 14(21.2 \%) & 12(18.2 \%) & \frac{\text { severe }}{2(3.0 \%)} & 0\end{array}$

Totally not A little

$18(27.3 \%) \quad 23(34.8 \%)$

Quite A lot $\frac{\text { Very much }}{7(10.6 \%)}$

Missing $10(15.2 \%) \quad \overline{8(12.1 \%)} \quad \frac{\text { (10.6\%) }}{7(10.6)}$

0

Always

$12(18.2 \%)$

Most of the

Often

Sometimes Seldom

$\underline{\text { Never }}$

Missing

Never $26(39.4 \%)$

$9(13.6 \%)$

$7(10.6 \%)$

$6(9.1 \%)$

$3(4.5 \%)$

$3(4.5 \%)$

Sometimes Often Most of the

$8(12.1 \%) \quad$ 25 (37.9\%)

$32(48.5 \%) \quad 12(18.2 \%)$ ime

$14(21.2 \%) \quad 5(7.6 \%)$

$1(1.5 \%)$

Always

0

$1(1.5 \%)$

Missing

$2(3.0 \%)$

$2(3.0 \%)$

Always

$7(10.6 \%)$

Most of the

$\underline{\text { Often }}$

Sometimes Seldom

Never

$\underline{\text { Missing }}$

$6(9.1 \%) \quad 13(19.7 \%)$
$12(18.2 \%) \quad 21(31.8 \%) \quad 7(10.6 \%) \quad 0$

$17(25.8 \%) \quad 14(21.2 \%) \quad 11(16.7 \%) \quad 2(3.0 \%)$ 
$\mathrm{MH} 4 \mathrm{sad}$

VT 3 exhausted

MH 5 happy

VT 4 tired

SF 2 During the last 4 weeks, how often did your physical or emotional problems limit you in your social activities (such as visiting friends or family)

GH 2 I seem to get sick more easily than other people

GH 3 I am as healthy as other people I know

GH 4 I expect my health to deteriorate

GH 5 My health is excellent

\begin{tabular}{|c|c|c|c|c|c|c|}
\hline & & & & Most of the & & \\
\hline Never & Seldom & $\underline{\text { Sometimes }}$ & $\underline{\text { Often }}$ & $\underline{\text { time }}$ & Always & Missing \\
\hline 16 (24.2\%) & 20 (30.3\%) & 18 (30.3\%) & $7(10.6 \%)$ & $1(1.5 \%)$ & 0 & $4(6.1 \%)$ \\
\hline 8 (12.1\%) & 18 (27.3\%) & 26 (39.4\%) & $6(9.1 \%)$ & $4(6.1 \%)$ & $1(1.5 \%)$ & $3(4.5 \%)$ \\
\hline
\end{tabular}

Always

Most of the

$\underline{\text { Often }}$

Sometimes Seldom

$\underline{\text { Never }}$

Missing

$6(9.1 \%) \quad \overline{31(47.0 \%)}$

$7(10.6 \%)$

$12(18.2 \%)$

$7(10.6 \%)$

Most of the

$\frac{\text { Never }}{3(4.5 \%)} \quad \frac{\text { Seldom }}{10(15.2 \%)}$

\section{Sometimes Often}

$22(33.3 \%) \quad 16(24.2 \%)$

time

0

$3(4.5 \%)$

Always $\quad$ Missing

Always

Most of the

time

$5(7.6 \%)$

\section{Sometimes Seldom}

Never

$16(24.2 \%) \quad 17(25.8 \%)$

$27(40.9 \%)$

$3(4.5 \%) \quad 3(4.5 \%)$

Completely

Mostly correct

$\underline{\text { d don't }}$

Mostly

Completely

Missing

correct

$1(1.5 \%) \quad 7(10.6 \%)$

know

incorrect

incorrect

Completely Mostly incorrect

$3(4.5 \%)$

incorrect

correct

Mostly correct

$3(4.5 \%) \quad 11(16.7 \%)$

Completely Mostly

incorrect incorrect

$6(9.1 \%) \quad 12(18.2 \%)$
$5(7.6 \%)$

I don't

know

$8(12.1 \%)$

I don't

know

34 (51.5\%)

I don't

know

$7(10.6 \%)$
Mostly

correct

$24(36.4 \%)$

Mostly

incorrect

$6(9.1 \%)$

Mostly

correct

$30(45.5 \%)$
Completely correct

18 (27.3\%)

Completely

incorrect

$10(15.2 \%)$

Completely

correct

$10(15.2 \%)$
0

Missing

$2(3.0 \%)$

Missing

$1(1.5 \%)$

Missing

$2(3.0 \%)$

Missing

$1(1.5 \%)$

Percentages are displayed according to total responders $(n=66)$. 
Supplementary table 6. Intercorrelation of the outcome measures

\begin{tabular}{lllllll}
\hline & $\begin{array}{l}\text { FFI } \\
\text { Pain }\end{array}$ & $\begin{array}{l}\text { FFI } \\
\text { Disability }\end{array}$ & $\begin{array}{l}\text { NRS } \\
\text { Pain }\end{array}$ & $\begin{array}{l}\text { SF-36 } \\
\text { PCS }\end{array}$ & $\begin{array}{l}\text { SF-36 } \\
\text { MCS }\end{array}$ & $\begin{array}{l}\text { Return to } \\
\text { daily } \\
\text { activity } \S\end{array}$ \\
\hline FFI Pain & 1 & $0.837^{* * *}$ & $0.850^{* * *}$ & $-0.714^{* * *}$ & $-0.377^{* *}$ & $0.504^{* * *}$ \\
FFI Disability & $0.837^{* * *}$ & 1 & $0.771^{* * *}$ & $-0.782^{* * *}$ & $-0.299^{*}$ & $0.600^{* * *}$ \\
NRS Pain & $0.850^{* * *}$ & $0.771^{* * *}$ & 1 & $-0.708^{* * *}$ & $-0.342^{* *}$ & $0.382^{* *}$ \\
SF-36 PCS & $-0.714^{* * *}$ & $-0.782^{* * *}$ & $-0.708^{* * *}$ & 1 & 0.174 & $-0.474^{* * *}$ \\
SF-36 MCS & $-0.377^{* *}$ & $-0.299^{*}$ & $-0.342^{* *}$ & 0.174 & 1 & -0.028 \\
Return to daily & $0.504^{* * *}$ & $0.600^{* * *}$ & $0.382^{* *}$ & $-0.474^{* * *}$ & -0.028 & 1 \\
activity $\$$ & & & & & & \\
\hline
\end{tabular}

Correlations were noted as $r$ - values. Pearson correlation was used whenever both parameters are continuous. Nominal parameters are marked $\$$. Spearman correlation was used when one of the parameters is not continuous.

If marked ${ }^{*},{ }^{* *}$, or ${ }^{* * *}$, the correlation model is statistically significant at the $0.05,0.01$ or 0.001 level respectively.

Abbreviations: FFI, Foot Function Index; VAS, Visual Analog Scale; SF-36, Short Form 36; PCS, Physical Component Summary; MCS, Mental Component Summary. 
Supplementary table 7. Stepwise multiple regression analysis

\begin{tabular}{|c|c|c|c|c|c|c|c|}
\hline & \multirow[b]{2}{*}{ Model parameters } & \multicolumn{2}{|c|}{$\begin{array}{l}\text { Unstandardised } \\
\text { coefficients }\end{array}$} & \multirow[b]{2}{*}{ p-value } & \multicolumn{3}{|c|}{ Model values } \\
\hline & & Beta & SE & & $r$ & $\mathrm{R}^{2}$ & p-value \\
\hline \multirow[t]{3}{*}{ FFI Pain } & Constant & 10.715 & 4.628 & 0.025 & 0.644 & 0.414 & $5^{\star} 10^{-6}$ \\
\hline & Osteoarthritis & 24.482 & 5.737 & 0.000 & & & \\
\hline & Body fracture & 13.745 & 5.856 & 0.023 & & & \\
\hline \multirow[t]{4}{*}{ FFI Disability } & Constant & 25.831 & 6.266 & 0.000 & 0.640 & 0.409 & $15^{\star} 10^{-6}$ \\
\hline & Osteoarthritis & 21.638 & 6.215 & 0.001 & & & \\
\hline & Delayed surgery & -14.953 & 6.256 & 0.021 & & & \\
\hline & Nonunion & 14.112 & 6.579 & 0.037 & & & \\
\hline \multirow[t]{3}{*}{ NRS Pain } & $\begin{array}{l}\text { Constant } \\
\text { Postoperative }\end{array}$ & 0.847 & 0.505 & 0.101 & 0.638 & 0.408 & $13^{*} 10^{-6}$ \\
\hline & complications & 2.24 & 0.596 & 0.001 & & & \\
\hline & Body fracture & 1.615 & 0.596 & 0.010 & & & \\
\hline \multirow[t]{5}{*}{ SF-36 PCS } & Constant & 46.274 & 2.533 & 0.000 & 0.715 & 0.512 & $2^{*} 10^{-7}$ \\
\hline & Osteoarthritis & -6.779 & 2.504 & 0.009 & & & \\
\hline & $\begin{array}{l}\text { Arthodesis } \\
\text { Articular }\end{array}$ & -14.899 & 4.176 & 0.001 & & & \\
\hline & incongruence & -9.801 & 2.739 & 0.001 & & & \\
\hline & Delayed surgery & 5.391 & 2.545 & 0.039 & & & \\
\hline \multirow[t]{2}{*}{ SF-36 MCS } & Constant & -7.959 & 2.289 & 0.000 & 0.350 & 0.123 & 0.005 \\
\hline & Body fracture & 53.762 & 2.289 & 0.005 & & & \\
\hline \multirow{5}{*}{$\begin{array}{l}\text { Return to daily } \\
\text { activity }\end{array}$} & Constant & 2.291 & 0.574 & 0.000 & NA & 0.506 & $5^{\star} 10^{-6}$ \\
\hline & Head fracture & -2.461 & 0.922 & 0.008 & & & \\
\hline & Gustilo grade & -0.877 & 0.330 & 0.008 & & & \\
\hline & $\begin{array}{l}\text { Dual approach } \\
\text { Ankle }\end{array}$ & -2.325 & 0.877 & 0.009 & & & \\
\hline & osteoarthritis & -2.032 & 0.813 & 0.012 & & & \\
\hline
\end{tabular}

This table represents an overview of the results obtained from our stepwise multiple regression analysis. For return to daily activity, a logistic regression model was used. For all other outcome parameters, a linear regression model was used. Only the final model is displayed. Abbreviations: SE, standard error; NA, not applicable; FFI, Foot Function Index; VAS, Visual Analog Scale; SF36, Short Form 36; PCS, Physical Component Summary; MCS, Mental Component Summary. 
Supplementary table 8. Fracture classification - Descriptives

\begin{tabular}{cc}
\hline Neck fracture* $^{*}$ & $30(45.5 \%)$ \\
Hawkins 1 & $10(35.7 \%)$ \\
Hawkins 2 & $13(46.4 \%)$ \\
Hawkins 3 & $3(10.7 \%)$ \\
Hawkins 4 & $2(7.1 \%)$ \\
Head fracture* & $10(15.2 \%)$ \\
Hawkins 1 & $6(60.0 \%)$ \\
Hawkins 2 & $1(10.0 \%)$ \\
Hawkins 3 & $0(0 \%)$ \\
Hawkins 4 & $3(30.0 \%)$ \\
Body fracture* & $47(71.2 \%)$ \\
Sneppen 1 & $0(0.0 \%)$ \\
Sneppen 2 & $7(15.2 \%)$ \\
Sneppen 3 & $8(17.4 \%)$ \\
Sneppen 4 & $7(15.2 \%)$ \\
Combined body fracture types & $18(39.1 \%)$ \\
Sneppen 5 & $6(13.0 \%)$ \\
\hline Percentages are displayed per total neck $(\mathrm{n}=30-\mathrm{i})$, head $(\mathrm{n}=$ \\
10-i) or body ( $\mathrm{n}=47-\mathrm{i})$ fractures in responding patients. With $\mathrm{i}$ \\
$=$ the number of missing data. \\
*Percentage displayed per total fractures in responding \\
patients $(\mathrm{n}=67-\mathrm{i})$. With $\mathrm{i}=$ the number of missing data. \\
Combined body fracture types are Sneppen 2 and/or Sneppen \\
3 and/or Sneppen 4 fractures.
\end{tabular}

Supplementary table 9. Outcome by surgeon that performed definite surgery

\begin{tabular}{|c|c|c|c|c|c|c|}
\hline Surgeon & $\begin{array}{l}\text { FFI } \\
\text { Pain }\end{array}$ & $\begin{array}{l}\text { FFI } \\
\text { Disability }\end{array}$ & $\begin{array}{l}\text { NRS } \\
\text { Pain }\end{array}$ & $\begin{array}{l}\text { SF } \\
\text { PCS }\end{array}$ & $\begin{array}{l}\text { SF } \\
\text { MCS }\end{array}$ & $\begin{array}{l}\text { Return } \\
\text { to daily } \\
\text { activity }\end{array}$ \\
\hline PR & 23.7 & 25.8 & 2.5 & 43.8 & 49.8 & $59.5 \%$ \\
\hline Other & 35.5 & 30.1 & 3.9 & 42.2 & 47.0 & $65.4 \%$ \\
\hline DM & 46.9 & 38.1 & 5.9 & 36.1 & 52.2 & $66.7 \%$ \\
\hline SN & 43.0 & 29.2 & 4.2 & 43.6 & 41.6 & $50.0 \%$ \\
\hline $\mathrm{HH}$ & 28.8 & 38.3 & 1.5 & 46.8 & 34.0 & $50.0 \%$ \\
\hline PB & 40.3 & 24.0 & 3.7 & 40.3 & 40.7 & $100 \%$ \\
\hline GM & 7.0 & 5.3 & 1.3 & 51.4 & 55.8 & $100 \%$ \\
\hline AS & 39.5 & 44.0 & 5.5 & 26.1 & 47.6 & $50.0 \%$ \\
\hline Fellow & 23.7 & 24.0 & 2.3 & 50.3 & 57.7 & $66.7 \%$ \\
\hline
\end{tabular}

The initials of the name of the surgeon are displayed. Surgeons are listed in order of the amount of talus fractures they operated. PR operated $55 \%$ of all talus fractures. Only three fractures were operated by a fellow. All other fractures were operated by staff surgeons. Continuous outcome scores are expressed as mean values. Return to daily activity is expressed as a percentage of all patients operated by a certain surgeon. Abbreviations: $\mathrm{FFI}$, Foot Function Index; VAS, Visual Analog Scale; SF-36, Short Form 36; PCS, Physical Component Summary; MCS, Mental Component Summary 


\section{1) Demografische gegevens:}

1. Geboortedatum

2. Geslacht

3. Lengte

4. Gewicht

5. Rookt u?

6. Hebt $u$ in het verleden gerookt?

7. Wat voor werk deed $u$ voordat $u$ het voet/enkelletsel heeft opgelopen?

8. Wat doet u nu voor werk?

$\bigcirc$
Ik heb dezelfde baan als voor het letsel Ik heb dezelfde baan, maar met aanpassingen Ik heb nu een andere baan / ben werkloos (NIET o.w.v. mijn voet/enkel)

$\bigcirc \quad$ Ik heb nu een andere baan (o.w.v. mijn voet/enkel)

$\bigcirc \quad \mathrm{lk}$ ben (vrijwel) niet meer in staat te werken o.w.v. mijn voet/enkel

$\bigcirc \mathrm{Ik}$ ben gepensioneerd, en mijn voet/enkel hindert mij NIET bij mijn dagelijkse activiteiten

$\bigcirc \quad \mathrm{lk}$ ben gepensioneerd, en mijn voet/enkel hindert mij bij mijn dagelijkse activiteiten

Links (u mag vraag 11 overslaan)

$\bigcirc$ Rechts (u mag vraag 11 overslaan)

Beiderzijds

11. Indien beiderzijds gebroken, welke voet/enkel heeft u de meeste klachten? $\bigcirc$ Links

$\bigcirc$ Rechts 


\section{2) Gegevens over de behandeling}

1. Hoe lang hebt $u$ gerevalideerd?

2. Hoeveel weken heeft $u$ uw voet niet mogen belasten?

3. Bent u met een gips of een brace nabehandeld?

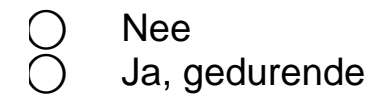
weken

4. Bent $u$ in een ander ziekenhuis dan UZ Leuven campus Gasthuisberg of campus Pellenberg geopereerd voor hetzelfde letsel?

5. Zo ja, wat is er gebeurd?

+/-___ weken

$\bigcirc \quad$ Ja
$+/-$ sessies bij de kiné,

of gedurende: +/(weken/maanden/jaren)

$\bigcirc$ Er is een plaat en/of schroeven toegevoegd

- Datum:

$\bigcirc \quad$ Er is materiaal verwijderd

- Datum:

- Waarom:

$\bigcirc$

Er is een prothese geplaatst

Datum:

Andere namelijk: 


\section{3) Voetpijn en Beperkingen Index}

(E. Budiman-Mak et al. 1991, modificatie volgens K.J. Gorter et al.)

\section{Vragenlijst voor mensen met voetklachten}

Geachte mevrouw, meneer,

Wij verzoeken u de vragen op de twee volgende pagina's betreffende "Pijn" en "Moeite met activiteiten" te beantwoorden. Met behulp van uw antwoorden kan de behandelend orthopaedisch chirurg het verloop van uw voetklachten beter volgen.

Het invullen van de vragenlijst duurt ongeveer 5 minuten. Leest u voor het invullen eerst de bijgaande instructies.

Hartelijke dank.

Instructies voor het invullen

De vragen hebben betrekking op de gevolgen van uw voetklachten in de afgelopen week, op uw dagelijks functioneren.

Streep bij elke vraag het antwoord aan dat het beste bij uw situatie past. Als u niet zeker weet hoe $u$ een vraag moet beantwoorden, geef dan het best mogelijke antwoord.

\section{Voorbeeld:}

Als $u$ de afgelopen week, als gevolg van uw voetklachten, slechts zelden schoenen droeg wanneer $u$ in huis liep, dan geeft $u$ dat als volgt aan:

\begin{tabular}{|c|c|c|c|c|c|c|}
\hline Antwoord: & nooit & zelden & $\begin{array}{c}\text { af en } \\
\text { toe }\end{array}$ & meestal & altijd & niet van toepassing \\
\hline $\begin{array}{l}\text { Hoe vaak droeg u schoenen } \\
\text { wanneer } u \text { in huis liep? }\end{array}$ & $\square$ & & $\square$ & $\square$ & $\square$ & $\square$ \\
\hline
\end{tabular}

Het kan voorkomen, dat de uitspraak niet op u van toepassing is, omdat $u$ de afgelopen week in het ziekenhuis opgenomen was en dus niet binnenshuis met schoenen kòn lopen. U kruist dan het hokje helemaal rechts "niet van toepassing" aan.

Voorbeeld:

\begin{tabular}{|c|c|c|c|c|c|c|}
\hline Antwoord: & nooit & zelden & $\begin{array}{c}\text { af en } \\
\text { toe }\end{array}$ & meestal & altijd & niet van toepassing \\
\hline $\begin{array}{l}\text { Hoe vaak droeg u schoenen } \\
\text { wanneer } u \text { in huis liep? }\end{array}$ & $\square$ & $\square$ & $\square$ & $\square$ & $\square$ & $x$ \\
\hline
\end{tabular}

U kruist eveneens "niet van toepassing" aan als u geen schoenen droeg, niet vanwege uw voetklachten maar omdat u bijvoorbeeld griep had.

Op de volgende pagina begint de vragenlijst. 


\section{Pijn}

Wilt $u$ bij de volgende vragen alleen een antwoord geven, als dit antwoord met uw voetklachten samenhangt; als dat niet het geval is, kruist u "niet van toepassing" aan.

Let op: Als èèn of meerdere situaties niet voorkwamen (bijvoorbeeld bij vraag $B 7$ en B8: $u$ heeft geen aangepaste zolen), dan kruist $u$ "niet van toepassing" aan.

\section{Vraag:}

Hoeveel pijn had $u$ in de afgelopen week aan uw voet in de volgende situaties?

$$
\begin{array}{ccccc|c}
\text { Geen } & \begin{array}{c}
\text { enige } \\
\text { pijn }
\end{array} & \begin{array}{c}
\text { nogal } \\
\text { pijn }
\end{array} & \begin{array}{c}
\text { veel } \\
\text { wat pijn }
\end{array} & \begin{array}{c}
\text { niet te } \\
\text { verdragen } \\
\text { pijn }
\end{array} & \begin{array}{c}
\text { niet van } \\
\text { toepassing }
\end{array}
\end{array}
$$

B1 Toen deze op zijn ergst was?

B2 Voor u uit bed kwam 's morgens?

B3 Bij lopen (= stappen) op blote voeten?

B4 Bij staan op blote voeten?

B5 Bij lopen (= stappen) met schoenen aan?

B6 Bij staan met schoenen aan?

B7 Bij lopen (= stappen) met inlays of aangepaste binnenzolen?

B8 Bij staan met inlays of aangepaste binnenzolen?

B9 Aan het einde van de dag?

$\begin{array}{llll}\square & \square & \square & \square \\ \square & \square & \square & \square \\ \square & \square & \square & \square \\ \square & \square & \square & \square \\ \square & \square & \square & \square \\ \square & \square & \square & \square\end{array}$




\section{Moeite met activiteiten}

Wilt $u$ bij de volgende vragen alleen een antwoord geven, als dit antwoord met uw voetklachten samenhangt; als dat niet het geval is, kruist u "niet van toepassing" aan.

Let op: Als èèn of meerdere situaties niet voorkwamen (bijvoorbeeld bij vraag C2 en C8: u kwam de afgelopen week helemaal niet buiten), dan kruist u "niet van toepassing" aan.

\section{Vraag:}

Hoeveel moeite had $u$ in de afgelopen week, als gevolg van uw voetklachten, om de volgende handelingen uit te voeren?

\begin{tabular}{|c|c|c|c|c|}
\hline $\begin{array}{l}\text { Geen } \\
\text { moeite }\end{array}$ & $\begin{array}{l}\text { enige } \\
\text { moeite }\end{array}$ & $\begin{array}{c}\text { nogal } \\
\text { wat } \\
\text { moeite }\end{array}$ & $\begin{array}{c}\text { veel } \\
\text { moeite }\end{array}$ & $\begin{array}{l}\text { niet toe } \\
\text { in staat }\end{array}$ \\
\hline
\end{tabular}

C1 Binnenshuis lopen (= stappen)?

C2 Buitenshuis lopen (= stappen) op oneffen terrein?

C3 500 meter of meer lopen (= stappen)?

C4 De trap oplopen?

C5 De trap aflopen?

C6 Op de tenen staan?

C7 Opstaan uit een stoel?

C8 Een stoeprand op- of afstappen?

C9 Snel lopen (=stappen) of rennen?
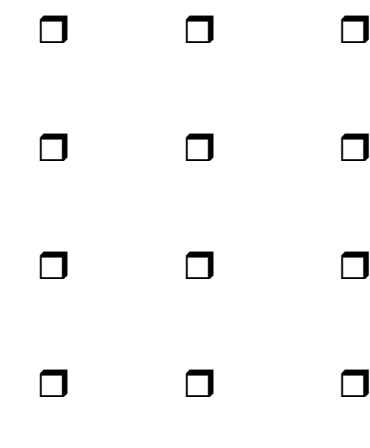


\section{4) NRS pijn score}

Hoe erg schat u de pijn ter hoogte van uw enkel in op dit moment?

Duid dit aan op onderstaande schaal.

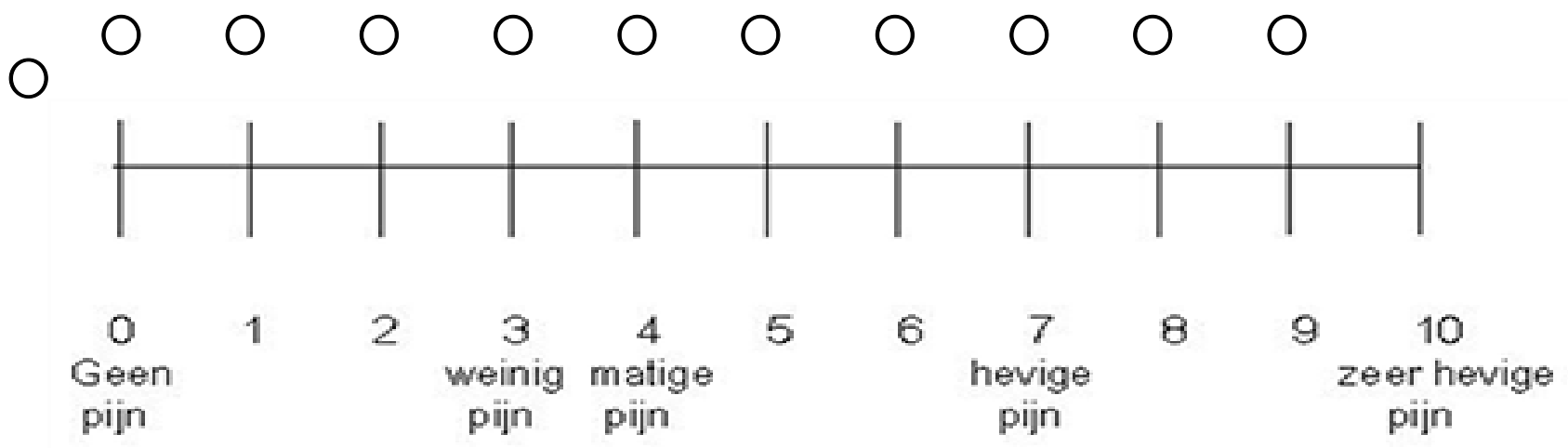

\section{5) Short Form 36 (SF-36)}

Deze vragenlijst gaat over uw gezondheid en de invloed van uw gezondheid op uw dagelijks leven. Met behulp van deze gegevens kan worden bijgehouden hoe $u$ zich voelt en hoe goed $u$ in staat bent uw gebruikelijke bezigheden uit te voeren. Wilt u elke vraag beantwoorden door het antwoord te markeren zoals aangegeven? Wanneer u twijfelt over het antwoord op een vraag, probeer dan het antwoord te geven dat het meest van toepassing is.

1. Wat vindt $u$, over het algemeen genomen, van uw gezondheid? (kruis één antwoord aan)

Uitstekend

Zeer goed

$\bigcirc$ Goed

$\bigcirc \quad$ Matig

Slecht

2. In vergelijking met een jaar geleden, hoe zou u nu uw gezondheid in het algemeen beoordelen? (kruis één antwoord aan)

$\bigcirc \quad$ Veel beter dan een jaar geleden

lets beter dan een jaar geleden

$\bigcirc$ Ongeveer hetzelfde als een jaar geleden

$\bigcirc \quad$ lets slechter dan een jaar geleden

$\bigcirc$ Veel slechter dan een jaar geleden 
3. De volgende vragen gaan over dagelijkse bezigheden. Wordt u door uw gezondheid op dit moment beperkt bij deze bezigheden? Zo ja, in welke mate?

(Kruis één antwoord aan)

\section{BEZIGHEDEN}

a Forse inspanning, zoals hardlopen, zware voorwerpen tillen, inspannend sporten

b Matige inspanning, zoals het verplaatsen van een tafel, stofzuigen, fietsen

c Tillen of boodschappen dragen

d Een paar verdiepingen trappen oplopen

e Eén verdieping opgaan

$f$ Vooroverbuigen, knielen of hurken

g Meer dan een kilometer wandelen

h Een paar honderd meter wandelen

i Ongeveer honderd meter wandelen

j Uzelf wassen of aankleden 
4. Problemen ten gevolge van uw lichameliike gezondheid DE AFGELOPEN 4 WEKEN (kruis één antwoord aan)

a $U$ besteedde minder tijd aan werk of andere bezigheden

b U heeft minder bereikt dan u zou willen

c U was beperkt in het soort werk of het soort bezigheden

d $U$ had moeite om uw werk of andere bezigheden uit te voeren (het kostte u bijvoorbeeld extra inspanning)

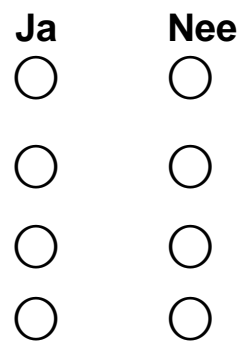

5. Problemen ten gevolge van emotionele problemen DE AFGELOPEN 4 WEKEN (zoals depressieve of angstige gevoelens)? (kruis één antwoord aan)
a $U$ besteedde minder tijd aan werk of andere bezigheden
Ja Nee
b U heeft minder bereikt dan u zou willen
C $U$ heeft het werk of andere bezigheden niet zo zorgvuldig gedaan als $u$ gewend bent
$\mathrm{O}$
$\mathrm{O}$

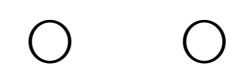

6. In hoeverre hebben uw lichamelijke gezondheid of emotionele problemen u gedurende de afgelopen 4 weken gehinderd in uw normale sociale bezigheden met uw gezin, familie, vrienden of buren, of bij activiteiten in groepsverband? (kruis één antwoord aan)

$\bigcirc$ Helemaal niet

Enigszins

$\bigcirc$ Nogal

$\bigcirc$ Veel

$\bigcirc$ Heel erg veel 
7.Hoeveel lichamelijke pijn heeft u de afgelopen 4 weken gehad? (kruis één antwoord aan)

$\bigcirc$ Geen

$\bigcirc$ Heel licht

Licht

Nogal

Ernstig

$\bigcirc \quad$ Heel ernstig

8. In welke mate bent u belemmerd door pijn de afgelopen 4 weken bij uw normale werkzaamheden (zowel werk buitenshuis als huishoudelijk werk)? (kruis één antwoord aan)
Helemaal niet
$\bigcirc \quad$ Een klein beetje
Nogal
Veel
$\bigcirc \quad$ Heel erg veel

9. Hoe vaak gedurende de afgelopen 4 weken (kruis één antwoord aan):

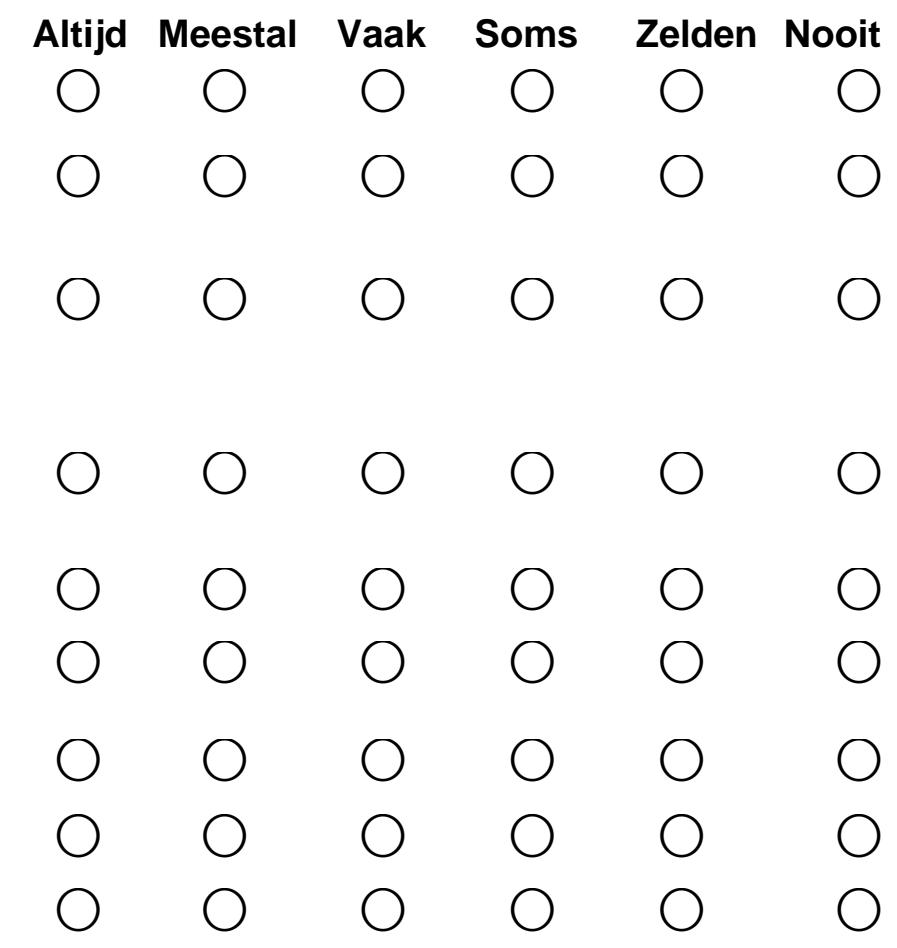


10. Hoe vaak hebben uw lichameliike gezondheid of emotionele problemen u gedurende de afgelopen 4 weken belemmerd bij uw sociale activiteiten (zoals bezoek aan vrienden of naaste familieleden)? (kruis één antwoord aan)

Altijd

Meestal

Soms

Zelden

O

Nooit

11. Wilt $u$ het antwoord kiezen dat het beste weergeeft hoe juist of onjuist u elk van de volgende uitspraken voor uzelf vindt? (kruis één antwoord aan)

a Ik lijk wat gemakkelijker ziek te worden dan andere mensen

Volkomen juist Grotendeels Weet ik Grotendeels Volkomen

lk ben even gezond als andere mensen die ik ken

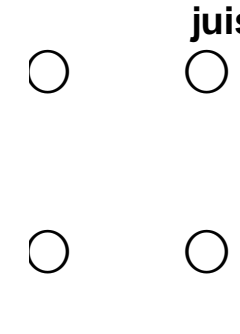
niet juist<smiles>O</smiles>
onjuist onjuist

c Ik verwacht dat mijn gezondheid achteruit zal gaan

$\bigcirc \bigcirc$<smiles>O</smiles>

d Mijn gezondheid is uitstekend

$\bigcirc$

